\title{
Florestan Fernandes: a criação de uma problemática
}

\author{
MIRIAM LIMOEIRO CARDOSO
}

$\mathrm{E}$ STOU ESTUdANDO a OBRA SOCIOlógICA de Florestan Fernandes, como momento privilegiado que ela me parece ser para a reconstrução de uma história da sociologia no Brasil (1). Analisando-a detidamente e buscando situá-la no tempo histórico em que é feita e nos lugares teórico, metodológico e político que ela passa a ocupar na comunidade científica e na sociedade brasileira vejo, cada vez com mais clareza, Florestan Fernandes como um construtor fundador. Trabalho com a suposição de que, ao exercer o seu ofício como cientista, Florestan se torna o criador de uma problemática nova, original e fecunda, que distingue a sua sociologia e exerce enorme influência em mais de uma geração de cientistas sociais no Brasil. Em torno dela se aglutinam outros importantes produtores, que lhe dão tratamentos variados e alcances diversos. Por meio dela, Florestan Fernandes contribui significativamente para o desenvolvimento da sociologia enquanto disciplina científica e, desse modo, atua como grande idealizador e propulsor da sociologia como atividade científica no Brasil (2).

Neste artigo, detenho-me no início da produção de Florestan Fernandes e tento localizar e apanhar no nascedouro as primeiras formulações da sua nova maneira de pensar o Brasil.

Para expor a teoria de um autor, não é necessário acompanhá-lo passo a passo ao longo da sua vida produtiva. No entanto, para conhecer a construção do seu pensamento, é preciso acompanhar as formas através das quais ele elege e formula o que toma como "seu problema", como o equaciona e como o resolve teórica e metodologicamente. Este procedimento é tanto mais importante quanto mais se esteja lidando com um autor que seja inovador na sua ciência. Para localizar o que ele traz de novo, é indispensável estudar, primeiro e cuidadosamente, a sua obra, no processo da sua produção e como produto acabado, para então cotejá-la com outras obras, de seus antecessores ou de seus contemporâneos.

A construção de uma problemática não se faz de repente, ainda que, quando completa, a nova formulação constitua um salto, uma diferença de qualidade com relação ao conhecimento anterior e contemporâneo. Uma produção como essa não se faz de uma hora para outra, sem aviso ou sem indícios; ela vai abrindo o seu caminho num processo original (há, portanto, uma espécie de história da 
sua construção). Também não se faz de saída (há, portanto, algo produzido que envelhece depois que o novo é alcançado). Não é necessário que este seja um processo muito demorado. Pode ser, ou não. Mas, com certeza, não se faz num único momento, sem ter um passado. A mim parece muito estimulante acompanhar o processo de criação aí envolvido.

Existem outros encaminhamentos, válidos também. Em geral, a percepção de estar diante de uma problemática nova se dá a partir do contato que se tenha com ela já constituída, quer dizer, conceitualmente precisa e teoricamente resolvida. A novidade de um encaminhamento ou de uma teorização confrontase com as idéias dominantes no período, idéias essas que fazem parte de formulações mais e menos sofisticadas do domínio científico e, também, de representações sociais e ideologias.

No caso da leitura que estou fazendo de Florestan Fernandes, a minha hipótese de fundo foi levantada deste modo, a partir do conhecimento do seu próprio trabalho e da produção sociológica da época, bem como do conhecimento das ideologias dominantes no Brasil e na América Latina no período (3).

Para ter acesso ao que é específico e distintivo de uma obra, um encaminhamento possível, e até em certos sentidos recomendável, é estudá-la "para trás", ou seja, no sentido inverso àquele percorrido pela sua produção concreta, tomando como ponto de apoio seus textos mais acabados, mais completos. A tentação de adotar esse caminho aqui, porém, defronta-se com a necessidade de seguir os passos do autor no seu próprio processo de produção, para acompanhar as diferentes problematizações que vai construindo, até as formulações mais claras e mais precisas. A ênfase é no processo, não no produto. Além disso, confesso, não resisti ao sabor de acompanhar o processo criador, de tentar ver nascer os modos novos de apreender a realidade e de construir o objeto, de me deparar com as possíveis indecisões e os possíveis avanços e recuos que, talvez, marquem a transição para uma nova maneira de pensar o objeto e de explicá-lo, em Florestan Fernandes.

Florestan é um teórico cuja produção é de primeira linha. Além de vasta, é rica e complexa. Quanto mais o estudo, e o venho fazendo há bastante tempo, mais percebo como os diversos temas sobre os quais trabalha se entrelaçam, se encontram, se mesclam, tendo muito a ver um com o outro. É bem por isso que sua obra é tão consistente. Essa consistência, porém, não significa que não haja mudanças de formulação e de encaminhamento ao longo dos 50 anos de sua atividade intelectual, nem que ela não tenha lacunas ou pontos mais frágeis.

No presente artigo procuro acompanhar a sua trajetória produtiva nas suas construções iniciais do que suponho venha a ser a base de uma nova problemática na sociologia produzida no Brasil. Aqui, utilizo apenas seus textos que 
envolvem pesquisa de natureza teórica geral. Portanto, ficam excluídos deste momento do estudo que envolvem análises mais pontuais ou tópicas e os trabalhos metodológicos e teóricos de orientação mais pedagógica.

Por enquanto, penso como um conjunto a sua produção que se estende de 1946 a 1967 (4). Não estou afirmando que 1967 corresponda a um ponto de inflexão na produção de Florestan Fernandes. Parece-me, mais, que 1967 marcaria o coroamento de um esforço interpretativo, em que ele já é capaz de demarcar com precisão metodológica, conceitual e teórica uma problemática inovadora, na qual vinha trabalhando desde 1955 , pelos dados de que disponho até o momento. O que estou apontando é que seus textos de 1967 como que concluem a construção do que ele provavelmente chamaria de esquema teórico de referência para a explicação do Brasil e do subdesenvolvimento/dependência/ heteronomia. Deste esquema, ele fornece as primeiras indicações em 1955 (em termos de "dependência cultural") e já expressa descobertas decisivas para elaborálo desde os textos de 1959 (formuladas enquanto "estado de dependência fundamental" e como "heteronomia econômica, política e social dos países subdesenvolvidos") e de 1960 (quando formula que a dependência econômica é a responsável pela heteronomia ideológica e moral, quando vincula a possibilidade de desenvolvimento fundamentalmente à dinâmica das relações entre as classes sociais e quando entende que o desenvolvimento autônomo das nações dependentes supõe como necessidade a aceleração da revolução social por que vêm passando). Em 1965 e 1967, completa a sua definição de capitalismo dependente, então já como um conceito, articulado a toda uma elaboração teórica e avança significativamente na pesquisa sobre as classes sociais sob o capitalismo dependente.

A leitura de um autor envolve sempre e necessariamente quem faz essa leitura. Uma leitura é sempre uma reconstrução da produção que o texto expõe, reconstrução que depende - da mesma forma que aquela produção - de quem a faz. A leitura propõe novos recortes sobre um objeto apresentado como texto, a partir das preocupações de quem lê, as quais dirigem a atenção mais para certas questões ou certos ângulos e que, assim, deixam de considerar outros tantos, que apareceriam mais sob um outro recorte. Estou ciente destas interferências, mas sei que elas fazem parte de todo processo de conhecimento. A objetividade que se possa conseguir na construção do conhecimento depende de que se enfrente de tais dificuldades e nào de que se negue de sua existência.

Na leitura cm yue estou atualmente empenhada é fundamental ser capaz de recollher e registrar, com a máxima precisào possivel, as idéias mestras do pens.amento em estudo e sula formulaçào nos conceitos em que porventura chegucm a sc cupress.r. Assumo que a precisão possível é fruto de decisões de leitura tomadas por mim, mas fundamento o meu csförço no que considero necessidade imperiosa, que é procurar alcançar, de fato, a obra de um ontro. É importante 
que eu consiga tratar essa obra efetiva e exatamente assim. Que ao tomá-la como meu objeto de conhecimento, fique claro que, com a construção do meu objeto, eu tento chegar até a especificidade de um outro pensamento e de uma outra reflexão, expressos na escrita do autor que estudo, outro que não eu. No caso, trata-se de tentar chegar até a sociologia de Florestan Fernandes. Um tal projeto de leitura requer o aguçamento máximo da capacidade de percepção, sem deixar que os objetivos e os viéses que a minha leitura possa ter a dirijam ao ponto de fazer com que eu encontre no objeto que investigo não seja senão aquilo que eu procurava antes mesmo de ter acesso a ele, porque então eu estaria encontrando apenas a mim mesma nessa leitura, sem conseguir alcançar efetivamente $o$ autor do texto que eu leio, nas formulações que sejam próprias dele. As leituras mais apressadas ou menos conscientes do seu próprio poder de interferência correm mais esse risco. Estou permanentemente atenta a ele e permanentemente me proponho a enfrentá-lo, reservando-me o meu direito ao exercício da leitura.

Com a consciência das implicações que uma leitura contém (como, ademais, qualquer construção de objeto de conhecimento) e com os cuidados teóricos, metodológicos e técnicos que essa consciência desperta, vejo-me na contingência de recorrer, para conseguir acompanhar o processo mesmo de criação de um problema e do seu equacionamento teórico, a freqüentes citações, para que a palavra do autor se faça, assim, presente no meu texto.

A ciência como valor:
explicação e aplicação

Para Florestan, a ciência é tomada como um valor. Nos primeiros textos que publica, dedica grande atenção a questões teórico-metodológicas e éticopolíticas. Pensa que a realidade social pode ser explicada e que à pesquisa científica, sistemática e rigorosa, cabe produzir essa explicação. Um tal conhecimento, porém, não deve esgotar-se na própria produção; deve ser produzido, por um lado, para o progresso da ciência e, por outro, para ser aplicado. O que orienta a sua compreensão da ciência, assim, é a unidade entre teoria e prática, à qual ele vincula a escolha dos objetos de investigação.

Entende a ciência na especificidade que lhe é própria, mas ainda na sua relação com a sociedade, da qual é parte, específica, mas parte. O desenvolvimento científico não resulta apenas do movimento de construção interna da própria ciência, mas também de condições histórico-sociais, as quais afetam a institucionalização da pesquisa e da formação científica, influenciam a mentalidade dos cientistas e interferem na identificação dos problemas a pesquisar. $O$ que vem a se tornar "problema de pesquisa", no entanto, é definido pelo pesquisador. A escolha do objeto de investigação e sua construção como problema depende da "sensibilidade" do cientista (sensibilidade que, para Florestan, está 
ligada à inserção particular do pesquisador na sociedade), da sua responsabilidade para com a própria ciência e do grau de responsabilidade social que assuma enquanto cientista, intelectual e cidadão. Deste modo, se tomar para si as responsabilidades inerentes à condição de cientista, escolherá como temas de pesquisa questões que possam fazer avançar o conhecimento científico e que tenham relevância social. Quanto, porém, a esta relevância social, Florestan entende que a ciência enquanto tal pode cumprir um papel importante, quando consegue revelar à sociedade aspectos que sejam decisivos para ela e que somente a descoberta científica alcance.

De acordo com Florestan, o conhecimento científico explicativo pode ser em si mesmo revolucionário se, ultrapassando e contrariando o senso comum e as representações dominantes, for capaz de atingir os nexos profundos, determinações da realidade, que regulem a ocorrência dos fenômenos característicos das questões cruciais socialmente. Um conhecimento desse tipo visa a descobrir relações necessárias e formulá-las sob a forma de leis que, no caso da realidade social, são leis históricas. Assim, preocupações com o rigor explicativo e com a aplicação do conhecimento científico estão presentes no pensamento de Florestan Fernandes desde o começo da sua produção científica.

Já na sua primeira introdução ao pensamento de Marx (Fernandes, 1946), Florestan manifesta esse tipo de preocupação. O que o interessa ali é o caráter científico da obra de Marx. É curioso quando recorre ao "sociólogo norte-americano Albion S. Small", na comparação que faz entre a importância de Marx nas ciências sociais e de Galileu nas ciências físicas (Fernandes, 1946:75) Esta sua Introdução, embora constitua produção de um jovem recém-formado na universidade, contém certas formulações que, ou aprendidas com Marx, ou produzidas como reflexões de apoio ao seu estudo, são reveladoras de uma concepção de ciência que Florestan Fernandes continuaria a defender nos seus textos mais maduros e a que tentaria dar corpo no seu próprio trabalho.

Ao se deter na questão das relações entre teoria e prática, lembra que "a economia, a sociologia etc. nasceram e desenvolveram-se sob o signo da ação; o ideal de seus fundadores era conseguir o controle da vida social para os homens, como já havia sido parcialmente realizado em relação às forças da natureza. Mais do que isso, pensavam em obter, por meio das ciências sociais particulares, técnicas sociais tão perfeitas que se poderia, no futuro, organizar racionalmente a sociedade, segundo planos sociais, econômicos etc., de modo a reduzir ao mínimo os desperdícios de energia humana e os desajustamentos sociais." Florestan comenta: "Todavia, apesar de toda a nostalgia da prática, teoria e ação são distanciadas de tal forma que, afinal de contas, tem-se o direito de perguntar a que espécie de aplicação aspiram e que eficiência prática pode ter uma teoria cuja prova é sempre ministrada teoricamente". Conclui, porém, com esperança esse 
comentário: "Nos últimos tempos, a posição de um Mannheim e a de um Freyer indicam claramente que essa atitude está se modificando, e que é possível esperar maior coerência para o futuro; também as ciências sociais têm alargado as suas esferas de aplicação" (Fernandes, 1946:81-82).

A questão de fundo para Florestan aí é a unidade entre teoria e prática, tal como supõe que ela esteja formulada em Marx. De uma certa maneira, sua lembrança de que as ciências sociais surgiram "sob o signo da ação" procura resgatar a dimensão da "ação" nestas ciências. Não critica o entendimento desta ação enquanto voltada para o "controle da vida social" e para a "organização racional da sociedade" por meio do planejamento. As reservas que apresenta se restringem ao que julga ser excessiva distância entre teoria e ação e ao fato de ser unicamente teórica a prova a que a teoria é submetida. O que, então, tais reservas encaminham? Primeiro, que teoria e aplicação fiquem mais próximas, sugerindo, assim, que ao ser construída a teoria leve em conta a sua aplicação, ou seja, que o objeto da teorização tenha a ver com as necessidades e as possibilidades de sua aplicação. Segundo, que o processo de prova da teoria não seja só teórico, mas inclua a prática, o que empresta outra importância e outro significado ao planejamento.

Aponta possibilidades de desdobramentos da aplicação do conhecimento científico, mas logo reconhece o risco de que se entenda a produção deste conhecimento como sendo autônoma e a aplicação como mero resultado de um movimento nascido da teoria. Por isso, procura deixar claro que o conhecimento científico tem sua base na realidade. Critica Sombart por não ter entendido isso em Marx. Diz, então: "De fato, ao contrário dos socialistas franceses, que combateu por esse motivo, Marx sabia muito bem que não podia construir a história do futuro em sua cabeça; o caráter científico que procurou dar ao socialismo compreendia submissão à realidade e ação racional. Mas submissão à realidade como meio e não como fim" (Fernandes, 1946:84). Submissão à realidade como meio corresponde à posição científica diante da realidade, posição em que é necessário procurar a máxima objetividade para poder explicá-la. Submissão à realidade como fim define uma posição política diante dela, posição conservadora de aceitá-la como ela é. No caso da realidade social, que é histórica, não aceitála significa opor-se à forma que historicamente ela apresenta, forma que, sendo histórica, por definição se transforma. Para opor-se a ela no sentido da sua transformação, no entanto, é preciso que se disponha de conhecimento sobre as ra\%õcs que a fazem ser tal como ela é. Deste modo, possibilidade de explicação não sc choca com possibilidade de intervenção na realidade social. Ao contrário, a cficácia da prática como ação racional não decorre da suposta racionalidadc ou justeza abstratas da teoria ou do projeto, mas da justeza da explicação. E a açào consciente e deliberada que faz uso do conhecimento efetivo da realidadc podc transformá-la, desde que sejam considerados os limites das suas determinaçòes. 
Penso que a fórmula "submissão à realidade e ação racional, mas submissão à realidade como meio e não como fim", Florestan a tomou para si permanentemente como organizadora da sua atitude na pesquisa e na ação.

Deste modo, em sua produção, desde cedo estão presentes considerações de caráter metodológico, ao lado de reflexões de natureza ética sobre a responsabilidade do cientista e do cidadão (5). As indicações de Florestan sobre a escolha dos objetos de investigação e a orientação para a aplicação dos conhecimentos produzidos pautam-se todo o tempo por sua relevância para o desenvolvimento da ciência social e por sua relevância histórico-social, sendo que esta é orientada sempre pela perspectiva de transformação social.

Quando estão dadas as condições para que o saber racional assuma a forma de saber científico, "na investigação positiva do objeto se procura, ao mesmo tempo, um critério para a descoberta da verdade e um instrumento para selecionar os conhecimentos considerados verdadeiros, reelaborá-los ordenadamente em um sistema de saber positivo e aplicá-los nas esferas em que se tomem decisões de significação vital para a coletividade" (Fernandes, 1955a:179). A indicação do que tenha ou não "significação vital para a coletividade" certamente não depende apenas nem principalmente do âmbito propriamente científico, mas cabe exatamente às descobertas da ciência localizá-lo como tal.

A ciência, ao descobrir nexos e relações causais muitas vezes insuspeitadas, cumpre - ou melhor, pode cumprir, ou não - um papel importantíssimo na localização de questões e de situações que, por serem chaves na cadeia explicativa, por isso devem ser consideradas como alvos preferenciais nos projetos de domínio inteligente dos fenômenos sociais. Essa compreensão é fortemente mobilizadora da atividade científica de Florestan, despertando e unindo num mesmo movimento a responsabilidade científica e a responsabilidade social. É ela ainda que exerce influência decisiva na escolha dos seus objetos de investigação.

Em produção um pouco mais recente (1960), enquanto vislumbra possibilidades de transformação qualitativa da ordem social em prazo mais ou menos curto, Florestan desenvolve uma expectativa bastante positiva quanto à aplicação dos conhecimentos sociológicos no planejamento social. É importante assinalar, porém, que em Florestan este é sempre um planejamento visando à reconstrução social, quer dizer, é projeção racional da construção de uma nova ordem social, como momento seguinte a uma revolução social, esta entendida como transformação profunda de uma forma determinada de organização social.

É assim, por exemplo, quando discute as "relações entre meios e fins na manipulação dos problemas sociais". Sugere que "nas fases de reconstrução social ... o homem precisa lançar mão, através do comportamento social inteligente, de técnicas sociais inevitavelmente complexas. ... Tanto o padrão, quanto o ritmo 
do desenvolvimento social passam a depender dos êxitos alcançados na utilização, em escala societária, dessas técnicas". Reconhece que "as condições histórico-sociais dos países latinoamericanos lhes são severamente adversas. Contudo, por paradoxal que pareça, elas são imprescindíveis, seja para o conhecimento positivo das exigências da situação histórico-social, seja para a descoberta e a exploração de modelos eficientes de mudança social progressiva". E conclui: "É provável, pois, que surjam disposições e incentivos mais favoráveis ao uso crescente de tais técnicas de controle social. Mesmo que isso não aconteça espontaneamente, os cientistas sociais devem estimular e orientar o processo, por todos os modos possíveis". Manifesta sua esperança de que, "na medida em que conseguirem explorar regularmente técnicas sociais racionais, é previsível que esses países poderão atingir com maior rapidez o limiar do desenvolvimento social" (Fernandes, 1960a:163; 1960b:269-270).

Florestan identificava naquele momento importantes processos de transformação social em curso na América Latina. Sua crença na razão e na possibilidade de eficácia do uso de técnicas racionais de intervenção na realidade social o motivavam a fazer avançar pesquisas voltadas para conhecer melhor a situação objetiva latinoamericana, por um lado, e as técnicas de controle social, por outro lado. Mesmo considerando que o meio social pode criar "limitações e impedimentos insuperáveis ou dificilmente superáveis", Florestan admite que "seria possível atuar de tal modo que os homens tomassem consciência destes fenômenos sociais e chegassem a dominá-los"(Fernandes, 1960a:141-142; 1960b:237238).

Quando escreve esses trabalhos, Florestan procura se encontrar como sociólogo no campo de uma sociologia rigorosamente científica, campo esse que ainda precisava ser construído no Brasil. Florestan compreende desse modo a situação e avoca para si a responsabilidade de empenhar-se naquela construção. Todo o esforço de implantação de uma sociologia "especificamente científica" não vai se limitar, com ele, ao campo estrito da ciência, porque para ele a produção mesma da sociologia científica depende da inserção que tal produção tenha na realidade histórico-social e da destinação que se pretenda dar a ela sob a forma de aplicação nessa realidade.

Ao analisar o desenvolvimento histórico-social da sociologia no Brasil e distinguir nele três épocas características, Florestan se situa inequivocamente na terceira delas. Na primeira, a sociologia teria sido apenas um recurso parcial, voltado para o esclarecimento de certas relações, em que se passava a incluir os fatores sociais. Na segunda, caracterizaria "o uso do pensamento racional como forma de consciência e de explicação", ou em termos de "análise histórico-geográfica e sociográfica do presente", ou alcançando um "modelo mais complexo de análise histórico-pragmática, em que a interpretação do presente se associa a 
disposições de intervenção racional no processo social". Já a terceira "subordina o labor intelectual no estudo dos fenômenos sociais aos padrões de trabalho científico sistemático" (Fernandes, 1955b:190). Sem dúvida, é este o padrão de trabalho científico que Florestan pretende para si mesmo. Ao se colocar como parte desse tipo de produção sociológica, é um equívoco supor que por isso ele assuma uma posição intelectualista ou academicista, envolvendo-se apenas com a "carreira" e com a construção institucional, como se fizesse - pelo menos durante um certo tempo - uma avaliação positiva desses dois móveis neles mesmos.

Sua posição já era, no começo da sua produção, e continuou sendo, de que a ciência (invariavelmente pensada por ele na sua especificidade enquanto trabalho sistemático, indissociável dos controles teórico e experimental) e a história estão sempre conjugadas: a ciência enquanto produto histórico (situada no desenvolvimento histórico desta ciência e parte do momento histórico da sociedade em que se produz) e também enquanto portadora da possibilidade de intervir na história (por meio das suas descobertas e explicações de níveis particularmente importantes para essa história real). "Entre os vários critérios que permitem apreciar a consistência e o grau de maturidade de uma disciplina científica qualquer, em determinado país ou em dada época, salienta-se o que indaga a respeito do alcance teórico das investigações. $O$ que caracteriza a marcha do pensamento científico não é a simples realização de pesquisas, nem certos atributos ou condições delas, como a habilidade em conduzi-las, os recursos materiais ou humanos postos à sua disposição, as possibilidades de repeti-las etc. É verdadeiro que a pesquisa ocupa um papel primordial na ciência, sendo por assim dizer a própria conditio sine qua non do conhecimento científico. Mas, a pesquisa constitui um meio, não um fim em si mesmo. A pesquisa pela pesquisa é tão abominável quanto o pensamento puramente especulativo. ... A ciência visa explicar a realidade, o que confere um fim à pesquisa e dá pleno sentido às atividades intelectuais dos cientistas" (Fernandes, 1956:35). O esforço para a produção da ciência não pode ser diletante. Até mesmo o alto custo envolvido nas tarefas de produção e de formação para a ciência requer outro tipo de resposta: em parte em direção ao progresso da própria ciência, o que exige escolhas pertinentes a esse progresso; e em parte em direção à sociedade, o que exige escolhas pertinentes, dessa feita, à transformação social.

A pesquisa é condição da ciência. Sem pesquisa não se faz ciência. Mas não basta "fazer pesquisa" para estar fazendo ciência. A ciência madura c consistente se mede pelo alcance teórico da sua pesquisa. A finalidade da ciência é explicar a realidade, o que já desqualifica a pesquisa pela pesquisa, bem como o pensamento especulativo. Mas, explicar o que? Certamente não é qualquer coisa. Não vale a pena pesquisar qualquer coisa, só vale pesquisar aquilo em que faça sentido aplicar os recursos disponíveis para pesquisa numa dada sociedade num dado momento. Esses recursos são escassos e envolvem escolhas da sociedade, que 
sacrifica alguma coisa quando aloca recursos aqui, e não ali. Essa escassez não se mede apenas pela riqueza ou pobreza relativa do país, mas também pela avaliação que a coletividade faça da importância da atividade científica, o que, em países como o Brasil, faz aumentar a responsabilidade das escolhas.

A questão de fundo nessa reflexão de que a medida da ciência é o seu alcance teórico consiste na indicação do que é significativo para a ciência e para a sociedade, do que é suficientemente significativo para justificar o gasto de dinheiro e de esforço que a pesquisa científica requer. $O$ que faz sentido procurar conhecer? O que a sociologia precisa para progredir como ciência? O que é importante para o desenvolvimento da sociologia científica no Brasil? A resposta está na identificação dos "problemas" que tenham relevância, teórica e social. Tais problemas não estão postos como tal, não estão dados, é preciso construílos, tendo em vista aqueles critérios de relevância. Nesse plano pratica-se a responsabilidade do cientista. Afinal, nessa instância ele pode influir nos rumos do desenvolvimento científico e do desenvolvimento social.

Estudando a "interação entre a ciência e a sociedade, tendo em vista a situação da investigação sociológica no Brasil", Florestan compreende a ciência não somente como campo específico com "normas e valores próprios", mas também como produto de um nível de determinação que provém das condições sociais. Diz que "os estudiosos da ciência costumam encará-la através de entidades intelectuais abstratas", em que a ciência aparece "como forma de saber positivo e o cientista como participante de um cosmos cultural autônomo, o qual possui normas e valores próprios, capazes de promover a ordenação das diferentes atividades intelectuais de cunho científico" (Fernandes, 1958:209). Como conse-qüência, "o trabalho do cientista pode e deve ser examinado à luz das obrigações, dos procedimentos e dos ideais que ... derivam ..., diretamente, da própria institucionalização das atividades científicas" (Fernandes, 1958:210). Florestan, porém, considera que "o conjunto de instituições que forma o 'sistema científico', pode ser entendido, etnologicamente, como uma subcultura". Isto é, mesmo ao ser considerado na sua especificidade, o campo da ciência faz parte de um conjunto mais inclusivo, que o abriga e o contém: a sociedade, com a sua cultura. A ciência, deste modo, mesmo na sua especificidade, deve ser considerada como parte de uma cultura maior. Portanto, é necessário "reconhecer que as condições sociais ambientes exercem uma influência ativa e contínua na organização e no funcionamento das instituições científicas, bem como na formação do horizonte intelectual do cientista" (Fernandes, 1958:210). Florestan atribui grande importância à relação entre as condições sociais e a perspectiva intelectual que o cientista acaba por assumir. Para ele, "a concepção liberal do mundo contribuiu para que se negligenciassem a significação e o alcance dos fatores extra-científicos na formação do horizonte intelectual do cientista. Avaliavam-se as investigações científicas e os seus resultados como se, no fundo, toda 
atividade intelectual de natureza científica fosse determinada, exclusivamente, pelas normas e pelos valores do saber científico. Entretanto, logo se descobriu que a escolha dos objetos das investigações, o grau de elaboração teórica dos seus resultados e, principalmente, as atitudes relacionadas com o destino prático a ser dado às descobertas realizadas dependiam, de maneira estreita, da influência construtiva exercida por outros sistemas de normas e de valores sobre a mentalidade média dos cientistas. Mesmo nos campos em que as atitudes dos cientistas parecem ser neutras, atrás delas ocultam-se inspirações intelectuais que se associam a concepções filosóficas, políticas, religiosas etc., das quais não se poderia dizer que sejam 'selecionadas' e 'aceitas' segundo os critérios do pensamento científico. Como Waddington conseguiu demonstrar, de modo magistral, a condição de cientista não isenta ninguém de agir com responsabilidade perante escothas que não podem ser feitas em termos estritos da ciência. $O$ essencial, para $o$ cientista moderno, consiste em proceder tais escolhas segundo uma estratégia consciente, que lhe permita realizá-las sem prejuízo da atitude e do conhecimento científicos e tendo em mira as vantagens que elas representam para a evolução da 'civilização científica'" (Fernandes, 1958:210-211).

Tratando do que eu chamaria de relação entre a ciência e a ideologia, Florestan identifica a origem liberal da idéia de sociedade parcelada, fragmentada, com o conseqüente isolamento das instâncias que a compõem (no caso, a ciência), como se não fossem parte dela. Deste modo, apresenta a ciência, pensada enquanto atividade isolada, independente, exercendo-se por si e voltada para si mesma como um produto idealizado pelo liberalismo. Florestan nunca vê a ciência fora da sua institucionalização. $\mathrm{E}$, enquanto atividade institucionalizada, é um contra-senso pensá-la cortando seus vínculos com a sociedade. Esses vínculos na verdade são constitutivos dela. Ao cortá-los, não é pouco o que se perde da ciência, nem é qualquer coisa. Penso que para uma história da sociologia no Brasil a questão colocada nesses termos abre um caminho muito fértil para a compreensào do que se estuda e do que se deixa de estudar ao longo do desenvolvimento do pensamento sociológico entre nós.

Se há uma determinação da mentalidade do cientista pela sociedade em que ele vive, por outro lado há uma resposta do cientista através do seu próprio trabalho às determinações e às expectativas da sociedade quanto a esse trabalho. De acordo com Florestan Fernandes, essa resposta deve sempre ser pautada pela ética.

Assim, balizados eticamente como intelectuais responsáveis, os sociólogos brasileiros "precisam associar suas ambições teóricas à investigação dos fenômenos sociais que ocorrem na sociedade brasileira", sem esquecer, no entanto, "que precisam contribuir para o progresso da sociologia como ciência" (Fernandes, 1958:213). Esse é o equilíbrio capaz de garantir a consistência científica e social do trabalho sociológico no Brasil. 
Florestan propõe "um novo padrão integrativo para o trabalho científico" do cientista social. Aponta para a necessidade e a capacidade do sociólogo brasileiro de "desenvolver um padrão de trabalho intelectual plenamente adequado à natureza do conhecimento científico, que ele precisa descobrir no campo das ciências sociais, $\mathrm{e}$ às funções extra-científicas que o mesmo conhecimento tende a preencher na vida social moderna. Assim, a ênfase nos fins empíricos da investigação permite atender a um requisito básico da explicação nas ciências sociais, que exige a reconstrução empírica dos fenômenos ou totalidades investigados, $\mathrm{e}$ às impulsões nascidas da necessidade de auto-consciência das condições de existência social, particularmente fortes onde a civilização industrial e urbana converteu a perspectiva historicista em dimensão natural da atividade humana. A ênfase nos alvos teóricos gerais da investigação relaciona-se, primariamente, com a obrigação intelectual específica do sociólogo, que consiste em contribuir para o progresso do pensamento científico na sociologia. Mas, ela também possui polarizações pragmáticas. É que, nas sociedades de organização democrática, a luta pelo poder e pela preservação ou transformação da ordem social pressupõe a inclusão, no nível intelectual médio, de conhecimentos que proporcionem alguma espécie de previsão sobre o curso futuro dos processos sociais. Por isso (como se poderia ilustrar com o liberalismo ou com o socialismo), semelhantes conhecimentos tanto servem como ponto de referência para a organização das atividades grupais nos movimentos sociais, quanto para legitimar, intelectualmente, os fundamentos de dada concepção do mundo. Por fim, a ênfase nas possibilidades práticas da investigação poderia parecer de interesse meramente utilitário. Graças a ela, os resultados da pesquisa sociológica seriam convertidos em conhecimentos e em orientações assimiláveis pelos leigos ou pelas instituições dedicadas ao planejamento e aos serviços sociais. No entanto, os desenvolvimentos recentes da sociologia aplicada sugerem que ela também concorre para o alargamento do campo de indagações teóricas da sociologia" (Fernandes, 1958:229-230). Aqui, Florestan Fernandes propõe um verdadeiro projeto para o desenvolvimento da sociologia no Brasil, conjugando pesquisa empírica e avanço teórico da sociologia enquanto disciplina científica a suas aplicações práticas. Seguindo esse projeto, pensa que pode se constituir no Brasil a sociologia cientificamente rigorosa e socialmente integrada, de forma a atender aos reclamos do progresso da ciência $\mathrm{e}$ às necessidades sociais do país.

\section{Da dependência cultural ao capitalismo dependente}

As formulações sobre as quais me detenho aqui datam dos anos 50 e 60 , época extremamente rica de acontecimentos, de produção e debate de idéias, de controvérsias intelectuais e políticas (6). É um período em que a ideologia do desenvolvimento é dominante no Brasil (7), desde suas concepções relativamen- 
te mais democráticas, sob Juscelino Kubitschek, até as mais autoritárias, sob a ditadura instalada pelo golpe de 1964.

Se há um tema que nesse momento chama para si as atenções de toda a sociedade, esse tema é “o desenvolvimento". Especialmente na segunda metade da década de 50 o apelo ideológico é forte, em nome do progresso e da riqueza material. $O$ desenvolvimentismo anuncia uma era de prosperidade, promovida pelo crescimento econômico acelerado. Há um termo que se impõe às discussões: "o arranco", ou "a arrancada para o desenvolvimento" (o take-off, cunhado por Rostow). Todas as preocupações se dão em torno disso, toda a mobilização se faz para isso. O outro lado desse apelo é político, mas também é para ser resolvido pelo econômico, com o crescimento: é a manutenção da ordem social, que a ideologia diz estar ameaçada pela miséria, já que a pobreza é tida como potencialmente geradora não só de intranqüilidade, como de revolta e de "infiltração de ideologias subversivas". Deste modo, o desenvolvimento econômico acelerado seria o antídoto necessário e urgente contra a expansão do comunismo. Como conseqüência, a caracterização global da ideologia desenvolvimentista juscelinista se contém na fórmula "mudar, dentro da ordem, para garantir a ordem".

É sobre esse fundo ideológico dominante que se desenrola a atividade intelectual, variada e complexa, naquele momento. A ciência também não escapa a ele, aí compreendida particularmente a ciência social, a não ser que consiga se afastar deliberadamente dessa influência ideológica e romper com ela. $O$ grande desafio é não se deixar prender nas malhas da ideologia dominante. Enquanto se faz oposição a aspectos do seu conteúdo (mesmo que se substitua esses aspectos por outros e por mais importantes que estes sejam), mas se continua a percebêlos e a pensá-los no quadro referencial armado pela ideologia, não se consegue sair das suas malhas. É complicado e dificil o rompimento com esse quadro referencial. Não se assume um outro quadro referencial sem sair deste, senão este "outro" não será mais do que uma parte, mesmo que diferenciada, daquela ideologia; se e enquanto estiver submetido à mesma matriz de pensamento da ideologia dominante, não pode se afirmar como efetivamente outro, diferente, com outros fundamentos e outro modo de pensar.

Florestan preocupa-se com as possibilidades, os condicionamentos $\mathrm{e}$ as exigências da constituição do saber científico no Brasil. Para ele, como vimos, a ciência é processo intelectual e é fenômeno histórico-cultural. Neste sentido, a atividade científica exige condições científicas e condições histórico-culturais e sociais (Fernandes, 1955a:159). Deste modo, o desenvolvimento da ciência se insere no fluxo da produção desta ciência, historicamente constituída enquanto história de um saber e no fluxo do desenvolvimento concreto da sociedade que a contém. 
Considerando, assim, a produção da ciência nos termos da sua inserção no campo específico da própria ciência e da sua inserção na sociedade, ao refletir sobre o desenvolvimento da sociologia no Brasil, tematiza a questão em termos de dependência cultural. Inicialmente, essa referência é apenas indicativa, quando diz que "a sociologia foi recebida no Brasil como 'novidade' intelectual, simultaneamente à sua criação na sociedade européia. Faz parte do processo da vida literária de povos culturalmente muito dependentes manter um intercâmbio excitado com os centros estrangeiros de produção intelectual. As 'novidades' assinaláveis tornavam-se rapidamente conhecidas, ainda que não fossem reelaboradas de uma forma autônoma. O destino do saber, acumulado desse modo, se regulava pelos padrões de vida literária que faziam dele, estritamente, uma forma de ilustração e um meio de alcançar notoriedade em círculos letrados" (Fernandes, 1955b:189). A forma pela qual Florestan utiliza aí a noção de dependência cultural revela que não se trata ainda de um conceito. No entanto, as idéias a que recorre para pensar a situação opõem, embora muito simplesmente, dependência e autonomia no plano cultural.

Colocada a questão, mesmo que incipientemente, Florestan a toma como parte importante da sua elaboração. Pergunta-se quais as razões desta situação de dependência cultural. As primeiras respostas que sua formulação encontra estão no nível das relações entre a produção intelectual e as necessidades e solicitações do meio social imediato da sociedade local. Compara "Brasil" e "Europa" como dois universos distintos: "Na Europa, os processos de desenvolvimento do pensamento, da economia e da sociedade podem ser interpretados como processos interdependentes. É visível a ligação do pensamento com a solução de problemas que se colocaram no plano da ação política oư da transformação econômica. No Brasil essa ligação não é perceptível com a mesma clareza, devido ao fato do saber racional utilizado não se ter constituído e desenvolvido como produto das exigências da situação histórico-social. Como ele era aceito preformado, do mundo cultural europeu, a sua incorporação a sistemas de concepção do mundo vinculados à sociedade brasileira muitas vezes exigiu reelaborações de sentido paradoxal. Isso, porém, não significa que essa 'Intelligentsia' fosse desinteressada, em face da solução dos problemas que se levantavam na esfera da ação. Faltaram-lhe ... elementos que permitissem inserir suas atividades intelectuais em um processo cultural dotado de dinamismo próprio" (Fernandes, 1955a:181182). Nesta análise, ainda basicamente descritiva, o que aparece como central ao raciocínio é o desequilíbrio entre pensamento, economia e sociedade, no caso em que o saber utilizado é saber transplantado de outro universo, no qual sua produção e seu uso pertenciam a um quadro global que se supõe equilibrado.

Levanta a significativa questão da falta de dinamismo próprio da Intelligentsia local. Florestan a atribui à dominação patrimonialista, ao horizonte intelectual modelado por essa forma de dominação e ao tipo de desenvolvimento 
institucional que ela propiciou. Avalia que "o desenvolvimento institucional da sociedade brasileirá, durante o século XIX, foi insuficiente para criar as condições que são indispensáveis à formação de um saber racional autônomo, capaz de evoluir como uma esfera especializada de atividades intelectuais. Daí a necessidade de apelar para os centros exógenos de produção de saber racional, toda vez que as exigências da situação histórico-social tornavam aconselhável ou inevitável o recurso a técnicas e a conhecimentos que possuíssem fundamento racional. O próprio ensino superior se constituíra, rapidamente, em uma maneira de organizar essa relação de dependência cultural diante dos países europeus. $O$ meio social ambiente não desencadeava forças culturais suficientemente fortes para estimular um novo estilo de pensamento ou para incentivar a transformação homogênea das escolas superiores em centros de pesquisa original" (Fernandes, 1955a:183).

Se o processo cultural não era dotado de dinamismo próprio, Florestan procura as razões na situação "interna" do país. Entende que se trata de incapacidade de produção cultural autônoma, devida a debilidades de natureza institucional, por sua vez decorrentes da organização política "interna" e das relações sociais que a conformavam. Por isso, a dependência cultural é identificada como sendo provocada pelo próprio país dependente, que, em determinadas circunstâncias, sente "a necessidade de apelar para os centros exógenos de produção do saber racional". Deste modo, a falta de produção intelectual criadora, original, autônoma é pensada fundamentalmente como decorrência da herança cultural e social da nossa sociedade, por sua origem na aristocracia agrária.

$\mathrm{Na}$ construção do objeto de investigação, a sociedade tomada como referência imediata da análise corresponde ao âmbito da nação. Num certo sentido, compara, como se fosse um sistema social inclusivo, "a sociedade brasileira" com outro sistema social inclusivo, identificado como "a Europa". No entanto, escapando desse nível mais imediato, o vínculo da cultura com "centros exógenos" de produção do saber racional indica que, mesmo que ainda não se defina com clareza, o sistema social inclusivo está além da sociedade brasileira.

Ainda na década de 50, em plena vigência do desenvolvimentismo juscelinista como ideologia dominante no Brasil, Florestan começa a trabalhar com uma nova problematização, que se tornará importantíssima para pensar não só o Brasil, como todo o "subdesenvolvimento" e o "desenvolvimento". O primeiro momento positivo deste encaminhamento é quando Florestan produz um novo recorte para o estudo da sociedade brasileira: quando toma, com clareza, como referência principal ou unidade de análise não a sociedade nacional, mas sim o que designa como civilização ocidental moderna ou capitalismo moderno. É importante notar como o eixo da pesquisa se desloca e como o seu objeto se reconstrói. $\mathrm{O}$ recorte definidor da unidade de análise sofrerá modificações no 
decorrer da pesquisa do próprio Florestan, que construirá seu objetō e o reconstruirá: primeiro, enquanto expansão capitalista mundial, entendendo a sociedade nacional como parte desta expansão; segundo, enquanto "forma de integração" das "sociedades heteronômicas ou dependentes" aos "centros de dominância" da expansão econômica capitalista; e terceiro, um pouco mais tarde, com a caracterização desta "forma de integração" como uma forma, particular e específica, que o desenvolvimento capitalista assume nas economias dependentes, com a construção do conceito de capitalismo dependente. Trata-se, a meu ver, de um processo progressivo de construção teórica, em que as noções vão se tornando mais precisas e se transformam em conceitos e em que uma nova problemática vai se delineando, ganhando contornos mais claros.

As reflexões que Florestan faz sobre esse tema em 1959 estão em seqüência àquelas que se encontram nos seus trabalhos de 1955, mas agora - com a definição mais nítida da escala de análise, que redefine o objeto - ganham em significado e em consistência conceitual e explicativa.

Este é tipicamente o caso de suas concepções de dependência e de heteronomia. Diz ele, num texto tão conciso quanto inovador e esclarecedor: "A integração do Brasil na órbita da civilização ocidental moderna fez-se por três vias diferentes. Primeiro, através da absorção contínua de populações imigradas da Europa ou de áreas em processo mais ou menos intenso de ocidentalização. Segundo, mediante o gradativo crescimento da teia de relações e de dependências da economia tropical brasileira com os centros de dominância da economia capitalista hodierna. Terceiro, pelos influxos de padrões de comportamento, de modelos de organização institucional e de valores ideais, extraídos da experiência histórico-social dos povos mais adiantados da civilização ocidental, na evolução interna da sociedade brasileira. As três vias se interpenetram e se completam" (Fernandes, 1959:167).

A primeira frase desta citação já motiva uma série de questões. Inicialmente, chama a atenção o lugar para onde a reflexão é dirigida. O foco da análise está no Brasil, mas também está fora dele, porque se situa nas vias ou nos modos de integração do Brasil à civilização ocidental moderna. As dificuldades de teorização ou a incapacidade explicativa no âmbito da sociedade nacional podem não ser primeiramente um problema de ordem intelectual. Talvez a explicação não possa mesmo ser formulada ao nível do objeto "sociedade nacional", caso sua própria constituição se dê num campo mais inclusivo. Isto é, se o Brasil é como é devido à forma da sua participação no desenvolvimento capitalista mundial, o entendimento do que o Brasil é, como ele é, depende da apreensão dessa forma de participação ou de integração. $O$ deslocamento da unidade de análise é, pois, condição necessária para alcançar o nível explicativo. 
A partir daí, a civilização ocidental moderna não é somente uma referência genérica de tipo de sociedade. A concepção histórica da expansão do capitalismo vinculada com a descoberta e com a colonização do Brasil adquire um novo significado, mais propriamente formativo, no sentido estrutural de uma expansão que se realiza integrando, diferenciadamente, seus novos componentes àqueles que comandam essa mesma expansão, seus polos. Assim se forma um amplo sistema, dentro do qual há posições diferenciadas, não simplesmente, mas sim organicamente diferenciadas. Isto é, essa diferenciação cumpre uma função na formação e no desenvolvimento do sistema. $\mathrm{O}$ "desenvolvimento" de países "subdesenvolvidos" no âmbito do capitalismo afeta a diferenciação que está estabelecida no sistema como um todo. Deste modo, se, sob certos aspectos, é uma questão nacional, de fato a questão não se resolve no plano nacional estrito, até porque ele não existe como tal.

Quando Florestan se refere à "integração do Brasil na órbita da civilização ocidental moderna", oferece nessa formulação um indicador daquela diferenciação, ao fazer uso do termo "órbita". O Brasil, como os demais países de mesmo tipo, não se integra à civilização ocidental moderna como mais um país, porque a civilização ocidental moderna se compõe de "centros de dominância" e outros países, que não são centros de dominância, mas que gravitam em torno desses "centros", na sua órbita. Um pouco mais tarde, o próprio Florestan recorrerá ao uso do termo "satélite" para expressar essa noção (Fernandes, 1967b:58; $1967 \mathrm{a}: 180 ; \ldots)$.

Até então, Florestan, permanentemente empenhado na caracterização especificamente sociológica do seu trabalho, apesar de considerar sempre o fator econômico e atribuir a ele grande importância, não o colocava no cerne mesmo do seu esquema analítico. Aqui, é bem isso que ele faz. Sua preocupação vinha sendo, e continuará sendo, com a organização e, principalmente, com a mudança social. Neste sentido, as questões relativas a padrões de comportamento, a modelos de organização institucional e a valores já freqüentavam suas pesquisas e já alimentavam a sua problematização da dependência cultural. Agora, no entanto, essas questões são colocadas ao lado, ou melhor, imediatamente a seguir, da via econômica da integração que ele quer entender.

Fala do "gradativo crescimento da teia de relações e de dependências da economia tropical brasileira com os centros de dominância da economia capitalista hodierna". Menciona, de um lado, a economia tropical brasileira e, de outro, os centros de dominância da economia capitalista. Percebe, pois, uma economia capitalista internacionalizada, com processos de dominância (sem esclarecer, por enquanto, em que consiste tal dominância, se o seu exercício implica subordinação ou apenas direção) e com alguma divisão internacional de tarefas, de funções ou de trabalho, cabendo à economia brasileira alguma especialização 
ligada à característica "tropical". Fala, ainda, de relações e de dependências entre essa economia tropical e os centros de dominância da economia capitalista, referindo-se a essas relações e dependências como uma teia (8), teia esta que, segundo Florestan, continua a ser tecida, já que ele se refere ao seu "gradativo crescimento". Ou seja, a teia de relações e dependências é um processo em curso.

As três formas mencionadas de integração do Brasil na órbita da civilização ocidental moderna organizariam a civilização ocidental aqui (não simplesmente no Brasil, mas em todas as regiões que têm a mesma condição que o Brasil). Logo perceberá que, com isso, "aqui" a civilização ocidental ganha uma especificidade toda própria e que, portanto, é preciso apreender e torná-la conceitualmente precisa.

Dentro deste quadro, a dependência cultural ganha novo patamar de entendimento. Segundo Florestan, "a tendência a procurar na Europa ou nos Estados Unidos a satisfação de extenso conjunto de centros de interesses e de valores alimenta um processo de alienação intelectual e moral de imensas proporções. Ao contrário do que se supõe comumente, o fato crucial não está, aqui, na procedência externa de categorias de pensamento e dos modos de agir, mas na maneira de interligá-los, que toma como ponto de referência permanente os núcleos civilizatórios estrangeiros, em que eles forem produzidos. Daí resulta um estado de dependência fundamental. Com isso, o processo de desenvolvimento interno se entrosa com valorizações e disposições subjetivas que concorrem, diretamente, para perpetuar e fortalecer a condição heteronômica da sociedade brasileira (Fernandes, 1959:172). A dependência cultural é recolocada sob a forma de alienação intelectual e moral. Uma coisa é apreender categorias de pensamento produzidas no exterior e utilizá-las para pensar nossa realidade, ainda que esta seja uma realidade diferente daquela onde tais categorias se originaram, embora pertençam ao mesmo conjunto civilizatório. Neste caso, a relação com essas categorias pode ser instrumental e esse caráter instrumental pode ser racional. Outra coisa é internalizar valores e disposições subjetivas de núcleos civilizatórios que nos dominam. Esta é uma forma de domínio (cultural), que é fortalecedora do outro lado deste mesmo domínio (econômico). É para esta alienação, que é cultural e também moral, que Florestan chama a atenção. Já não se trata apenas de encontrar razões da dependência cultural numa incapacidade de produção intelectual autônoma, que derivaria de formas patrimonialistas de dominação.

É posto em pauta um certo tipo de identificação, não como um processo psicológico, mas como um processo sócio-político. Enquanto o "subdesenvolvido" vê o "desenvolvido" como a presença ou a encarnação de um estágio de civilização mais avançado ou mais adiantado (e, portanto, se reconhece como estando em atraso), a identificação com as valorizações e disposições subjetivas 
"desenvolvidas" (que se traduz no desejo de alcançar aquele estágio avançado, "desenvolvido") pode ser considerada e aceita como construtiva do país e da nacionalidade, especialmente, quando e se, desde as suas mazelas e misérias até a sua "dualidade estrutural" são atribuídas àquele atraso ("subdesenvolvimento").

No entanto, isso muda radicalmente quando o entendimento do subdesenvolvimento como atraso é substituído por heteronomia ou dependência, no sentido que Florestan dá a esses conceitos. Desde essa nova perspectiva, a introjeção de valores e disposições subjetivas dos centros de dominância pelos satélites submetidos a essa dominância passa a ser considerada como alienante ou como produtora de alienação intelectual e moral. A compreensão de todo o processo de desenvolvimento dos povos subdesenvolvidos sofre aí uma transformação profunda, capaz de criar repercussões importantes não só no plano científico, mas também no plano político. Isso porque se traz para o centro da cena todo um mecanismo (que não é imediatamente perceptível) através do qual o próprio desenvolvimento, pretendido como identificação com os "desenvolvidos", fortalece e perpetua a heteronomia. Segundo Florestan, "daí resulta um estado de dependência fundamental". Apresentado pela ideologia dominante, desenvolvimentista, como salvação, o desenvolvimento aparece nessa análise como agravamento do problema.

A oportunidade de refletir sobre casos de nações que também se encontram em situação de dependência, mas que contam com civilização própria, rica e complexa - diferentemente de nações cujo processo civilizatório foi constituído de forma semelhante ao do Brasil - repercute fortemente no pensamento de Florestan. É num momento assim que ele põe em questão os limites de sua antiga reflexão sobre a dependência cultural, formula a situação dos países subdesenvolvidos em termos de heteronomia ou dependência e caracteriza a condição heteronômica como sendo econômica, política e social. Considera que "a intensificação das relações com países que estavam ou ainda estão em situação análoga ao Brasil ... poderá contribuir, como vem acontecendo, para facilitar e aprofundar tanto a percepção, quanto a explicação dos fatores da heteronomia econômica, política e social dos países subdesenvolvidos. Aqui não está em jogo, apenas, a idéia de que os demais países subdesenvolvidos oferecem ao Brasil uma imagem de suas condições de dependência diante das nações plenamente desenvolvidas do Ocidente. Várias nações do Oriente possuem civilizações próprias, tão ricas e complexas quanto a civilização ocidental. Essa é uma evidência, claramente perceptível e inteligível, de que a condição heteronômica não é mero produto da falta de 'originalidade' cultural" (Fernandes, 1959:172). Uma compreensão como esta o leva a discutir a importância e a descartar a centralidade da dependência cultural. Pode-se procurar muitas razões para entender sua preocupação tão forte com o caráter cultural da dependência, praticamente desde os seus primeiros escritos. $\mathrm{O}$ certo é que no seu percurso como produtor Florestan 
Fernandes percebeu mais cedo a dependência na sua dimensão cultural e a considerou como um verdadeiro obstáculo, por suas conseqüências internas, ao “desenvolvimento". No confronto com nações com cultura própria e rica e que, apesar disso, são dependentes, Florestan questiona frontalmente a eficácia da dependência cultural como impedimento ao desenvolvimento autônomo. Se povos com cultura própria, rica e complexa também se encontram em condição heteronômica, a dependência cultural não pode ser tão central à condição dependente, menos ainda responsável por ela, ainda que possa ser muito importante (negativamente) na luta contra ela.

Com isso, a cultura não se ausenta das preocupações de Florestan. Mas aparece cada vez mais tematizada enquanto ideologia e cede espaço a reflexões mais propriamente econômicas e políticas. Condizente com essa nova perspectiva, as classes sociais e suas relações passam a ganhar destaque e centralidade nas suas análises.

Num importante texto de 1960 , aceitando como tema a aceleração do desenvolvimento, Florestan se pergunta sobre as razões das dificuldades e dos bloqueios que tal aceleração tem encontrado na América Latina e o que é possível e necessário fazer para enfrentar e superar esse impasse. A perspectiva que assume é claramente a do desenvolvimento autônomo. Num campo assim posto, vai firmando os contornos da sua concepção de dependência e heteronomia, passando a enfatizar no seu esquema analítico não apenas a consciência social, mas também as classes sociais. Conclui não pela aceleração do desenvolvimento, direta ou imediatamente, mas pela necessidade de aceleração da revolução social como condição mesma do desenvolvimento. Diz que "é possível entender a utilidade das instituições e importá-las em vista disso. Contudo, não é tão fácil produzir as condições de organização e funcionamento que elas requerem. ... Assim se define a situação de heteronomia e dependência básica dos países subdesenvolvidos. Malgrado as possibilidades de representarem seus destinos segundo conceitos tomados aos povos plenamente desenvolvidos do mesmo sistema civilizatório, eles não possuem condições materiais e morais que assegurem o domínio eficaz de padrões de desenvolvimento autônomo. Essa situação histórico-cultural tem gerado ressentimentos e frustrações coletivos, os quais alimentam antagonismos contra os países que fornecem os modelos da imagem nacional refletida ou incentivam atitudes de desalento e conformismo. Nenhum povo gosta de saber que sua dependência econômica possui ramificações que conduzem à heteronomia ideológica e moral, nem que seu poder sobre os próprios destinos se confina a um padrão reflexo e dependente de desenvolvimento interno" (Fernandes, 1960a:156; 1960b:261-262).

A pergunta subjacente a esta reflexão é: por que os povos subdesenvolvidos, quando acatam o projeto do desenvolvimento acelerado, representam o seu fu- 
uuro de acordo com ele e se empenham em alcançá-lo, não o conseguem?.Em que consiste esta "realidade" que "resiste"? Suas respostas repousam no descompasso entre representação (ideológica) e condições históricas reais. Não basta importar instituições que se julgue úteis, porque enquanto representações elas não funcionam na prática. É preciso fazê-las funcionar, é preciso criar "as condições de organização e funcionamento que elas requerem”. Aderir à idéia de desenvolvimento, e mesmo desejá-lo, não põe em marcha o desenvolvimento na realidade concreta. Não é tão fácil "produzir as condições" para torná-lo historicamente efetivo. É essa falta de "condições materiais e morais que assegurem o domínio eficaz de padrões de desenvolvimento autônomo" que Florestan há muito identificava como dependência cultural. Enquanto o obstáculo ou o bloqueio é entendido nesse plano, a ação para superá-lo e ultrapassá-lo tende a restringir-se também ao mesmo plano, quer dizer, situa-se na dimensão da cultura, da ordem intelectual e moral. Mas Florestan irá rapidamente deslocá-lo na sua análise para o plano político das relações entre as classes e o poder.

Apesar de sua antiga insistência na dependência cultural, Florestan opera nesse momento uma transformação decisiva: "nenhum povo gosta de saber que sua dependência econômica possui ramificações que conduzem à heteronomia ideologica e moral". Aquilo que constituía substantivamente o conceito de dependência cultural nas formulações iniciais de Florestan Fernandes e que agora ele trata como heteronomia ideológica e moral, passa a ser pensado como parte de um conjunto bem integrado. A especificação desse conjunto (formado pela dependência econômica e pelas ramificações que esta possui e que "conduzem à heteronomia ideológica e moral") confere um sentido novo à concepção de heteronomia em Florestan. Assim é que, no interior do sistema formado pela . expansão da civilização ocidental moderna há os centros dessa expansão e os países que participam dela, mas são privados de autonomia. Esta condição heteronômica é econômica, política e social ou econômica, ideológica e moral. Ou seja, a condição heteronômica é global, sendo que nela é a dependência econômica que responde fundamentalmente pela heteronomia. $O$ encaminhamento da explicação da dependência cultural pela via exclusiva ou principalmente interna se desloca para o plano internacional e é o conjunto da condição heteronômica, no qual a determinação cabe à dependência econômica, que dá sentido à dependência cultural. A via interna da explicação se mantém, mas em plano subordinado.

A heteronomia não é formalizada no plano legal, como acontecia na era colonial, mas é sumamente eficaz, já que a integração econômica satelizada se desdobra culturalmente, na construção das mentalidades e das aspirações, de tal modo a criar comportamentos, expectativas e laços que reforçam a condição heteronômica. Pelo menos dois aspectos desta colocação merecem atenção especial. Um é que toda a reflexão se apóia na concepção de desenvolvimento autônomo. 
É examinando a autonomia, suas possibilidades, suas limitações e as obstruções a ela nos povos dependentes que se recorre ao par autonomia/heteronomia. A perspectiva do desenvolvimento autônomo estabelece uma diferença de base e de fundo com relação às idéias desenvolvimentistas vigentes. Ela é assumida, porém, por posições políticas as mais diferentes, que lhe dão, é evidente, configurações bem distintas.

O desenvolvimentismo faz convergir as atenções para o econômico. Sua proposta central é o crescimento econômico, avaliado por indicadores basicamente econômicos. As discussões que suscitava eram, desse modo, socialmente conduzidas para o campo econômico, desde que o desenvolvimentismo se tornou dominante como ideologia no Brasil. As oposições a ele em geral não deixaram de trabalhar no mesmo campo, embora tendessem a sublinhar a dimensão do político, em especial quando assumiam feições nacionalistas, organizadas principalmente em torno da oposição entre capital estrangeiro e capital nacional, bem como da soberania nacional e do desenvolvimento autônomo. O lado político do projeto desenvolvimentista, que o apresenta como guardião da ordem estabelecida, ficava numa certa medida encoberto pela exacerbação da ênfase posta no crescimento econômico acelerado. Essa face assumirá o primeiro plano depois de 1964.

Florestan participa intensamente do debate intelectual que se trava no período e nele reconstrói os caminhos para a sua própria análise, sempre preocupado com o "sistema de referência" e a necessidade de que ele permita alcançar o que seja "essencial". Percebe que "tem-se acentuado a tendência, por parte dos intérpretes da situação brasileira, a dar importância crescente às categorias do pensamento econômico e aos fatores econômicos. Aos poucos, o quadro histórico-social geral deixou de ser o sistema de referência das análises, e os fatores histórico-sociais passaram a segundo plano. Em conseqüência, as explicações descobertas tendem a perder de vista o essencial: as determinações mais amplas e centrais a longo termo, que estruturam e dinamizam as relações entre a Economia e a Política. Doutro lado, o conhecimento de senso comum propende a avaliações de cunho ideológico, que gravitam em torno dos interesses típicos dos setores empresariais, rurais e urbanos" (Fernandes, 1966:135-136). Florestan procura resgatar a dimensão histórico-social, para não perder de vista o essencial. Refletindo sobre a intensidade e as limitações ao crescimento econômico,'reorienta a problematização da questão tal como ela costuma ser posta e afirma que "a questão fundamental, para o sociólogo, não está nas expressões quantitativas assumidas pelo crescimento econômico em dado período de tempo. Mas em determinar se elas correspondem, estrutural e dinamicamente, ao padrão de integração econômica da civilização vigente" (Fernandes, 1966:136). 
$\mathrm{Na}$ altura em que escreve esse texto, Florestan já tem muito claro que "o padrão de crescimento econômico que regula atualmente a organização e a expansão das atividades econômicas no Brasil é típico de uma economia capitalista diferenciada, mas 'periférica' e 'dependente'. Ao nível estrutural, ele é insuficiente para promover a integração balanceada, em escala nacional, da produção, da circulação e do consumo, nos moldes da civilização vigente (os quais pressupõem uma economia capitalista 'avançada'). Ao nível dinâmico, ele é insuficiente para promover o desenvolvimento econômico auto-sustentado e autônomo, segundo os mesmos moldes. Como nasce e responde a uma relação de dependência crônica, no mercado internacional, o crescimento neste nível antes concorre para manter a influência dos centros hegemônicos externos, que para provocar sua substituição pelos 'centros de decisão' internos ou para criar o tipo de autonomia econômica requerido pela economia capitalista integrada ou pelo Estado nacional independente a que ela se associa. Ao nível do sistema sociocultural global, em que a economia se insere, é insuficiente para dar lastro econômico adequado à integração, ao funcionamento e ao desenvolvimento da ordem social, ainda levando-se em conta os moldes da civilização vigente" (Fernandes, 1966:145-146).

Privilegiando para a sua análise os fatores histórico-sociais e direcionando essa análise para o "padrão de integração" das economias em busca de crescimento econômico acelerado com a "civilização vigente", sua compreensão da situação de países como o Brasil já se faz em termos de que tal situação constitui um tipo particular de economia capitalista, sendo que a particularidade que a diferencia é ser "periférica" e "dependente".

Florestan quer "entender, sociologicamente, por que a independência não gerou uma nação livre e integrada; e por que o crescimento econômico, associado à expansão interna do capitalismo e à industrialização, não fez outra coisa senão manter sua posição dependente em relação ao exterior" (Fernandes, 1967a:173). Fala de "uma teia invisível de dependências econômicas, criada pelo próprio capitalismo ao nível da organização internacional da economia", que sob o "imperialismo econômico" criou "um padrão de desenvolvimento econômico pelo qual o crescimento econômico das nações satélites ficava subordinado aos interesses, à política e às potencialidades econômicas das nações dominantes", caracterizando "uma economia capitalista dependente". Entende que, sob o "capitalismo industrial, a Nação atinge o seu maior nível de riqueza e de desenvolvimento, mas configura, igualmente, a plenitude do capitalismo dependente" (Fernandes, 1967a:176). Se o aumento da riqueza e do desenvolvimento mantém e até amplia a dependência, da perspectiva do desenvolvimento autônomo a questão decisiva para esses povos não pode ser a implementação ou a aceleração do desenvolvimento econômico e sim a questão de saber como alcançar "a verdadeira dependência econômica, social e cultural". 
Ao participar de um Colóquio na Universidade de Münster sobre "Problemas das Sociedades em Desenvolvimento Industrial", Florestan produz um trabalho que sintetiza suas formulações elaboradas até então sobre a dependência. Nesse belo texto, fica claro o seu entendimento de que "o subdesenvolvimento explica-se, objetivamente, pelas condições de dependência ou de heteronomia econômica. Mercados e economias capitalistas, construídos para serem operados como satélites, organizam-se e evoluem segundo as regras e as possibilidades do capitalismo dependente. Assim, o subdesenvolvimento não é um estado produzido e mantido a partir de dentro, mas gerado, condicionado e regulado a partir de fora, por fatores estruturais e de conjuntura do mercado mundial" (Fernandes, 1967b:58). Não está interessado somente na explicação do subdesenvolvimento, mas também na sua superação. Seguindo aquela explicação, "a ruptura do subdesenvolvimento se identifica com o repúdio ao capitalismo dependente e só pode desencadear-se, em condições econômicas internas 'favoráveis' ou 'desfavoráveis', a partir de dentro"(Fernandes, 1967b:58).

Para discutir o tema proposto, inicia o texto afirmando: "O capitalismo não é apenas uma realidade econômica. Ele é também, e acima de tudo, uma complexa realidade sociocultural, em cuja formação e evolução histórica concorreram vários fatores extra-econômicos (do direito e do Estado nacional à filosofia, à religião, à ciência e à tecnologia). Na presente discussão, esse ponto de vista é aplicado à análise das influências estruturais e dinâmicas da ordem social global sobre a absorção e a expansão do capitalismo no Brasil, uma sociedade nacional do 'mundo subdesenvolvido'" (Fernandes, 1967:21). Repudia de saída a noção de "sociedade em desenvolvimento". Toma como referencial da análise "o capitalismo" e como objeto a relação entre "uma sociedade nacional do 'mundo subdesenvolvido' e o capitalismo em expansão". Nesse objeto, seu problema são "as influências estruturais e dinâmicas da ordem social global sobre a absorção e a expansão do capitalismo no Brasil".

Quando da independência política, reconhece que "as estruturas sociais e econômicas do mundo colonial ficaram intactas, como condição mesma, seja para o controle do poder pelas elites senhoriais nativas, seja por causa das necessidades do mercado mundial, em relação ao qual a economia tropical preenchia uma função especializada de natureza heteronômica" (Fernandes, 1967b:23). Identifica ao longo de nossa história "uma condição colonial permanente, embora instável e mutável", acrescentando estar claro "que essa condição se altera continuamente: primeiro, se prende ao antigo sistema colonial; depois, se associa ao tipo de colonialismo criado pelo imperialismo das primeiras grandes potências mundiais; na atualidade, vincula-se aos efeitos do capitalismo monopolista na integração da economia internacional. Ela se redefine no curso da história, mas de tal modo que a posição heteronômica da economia do País, em sua estrutura e funcionamento, mantém-se constante. O que varia, porque depende 
da calibração dos fatores externos envolvidos, é a natureza do nexo de dependência, a polarização da hegemonia e o poder de determinação do núcleo dominante" (Fernandes, 1967b:26).

Entende que "no plano internacional, o capitalismo gera uma luta permanente e implacável pelas posições de controle da economia mundial, que permite dirigir os processos de formação e de crescimento das economias dependentes, bem como monopolizar os excedentes econômicos que podem, assim, ser captados e drenados dessas economias para as economias hegemônicas" (Fernandes, 1967b:35). O fundamental é identificar o caráter permanente de relações que se apresentam como mutáveis, o que significa identificar o quanto há de relativo nestas mudanças. Reconhecer a luta "permanente e implacável" pela hegemonia da expansão capitalista mundial faz com que o confronto com "o país" que num dado momento exercia aquela hegemonia perca muito do sentido que possuía antes daquele reconhecimento ser colocado. Estruturalmente, o importante é a própria relação entre centros hegemônicos no plano mundial (que variam historicamente, deslocando-se de uma economia a outra) e as economias e sociedades politicamente organizadas em plano nacional.

Florestan acaba por formular sob a forma de conceito o capitalismo dependente, como "uma situação específica, que só pode ser caracterizada através de uma economia de mercado capitalista duplamente polarizada, destituída de auto-suficiência e possuidora, no máximo, de uma autonomia limitada. ... Nos planos da estrutura, funcionamento e diferenciação do sistema econômico, a dupla polarização do mercado suscita uma realidade nova e inconfundível. Trata-se de uma economia de mercado capitalista constituída para operar, estrutural e dinamicamente: como uma entidade especializada, ao nível da integração do mercado capitalista mundial; como uma entidade subsidiária e dependente, ao nível das aplicações reprodutivas do excedente econômico das sociedades desenvolvidas; e como uma entidade tributária, ao nível do ciclo de apropriação capitalista internacional, no qual ela aparece como uma fonte de incrementação ou de multiplicação do excedente econômico das economias capitalistas hegemônicas" (Fernandes, 1967b:36-37). O mais importante e que singulariza a formulação deste conceito como contribuição teórica de relevo é que a dependência aqui não é mais apenas um mecanismo de relação entre partes diferenciadas de um mesmo sistema, mas ganha a dimensão de uma forma própria, particular e específica do desenvolvimento capitalista.

Com a discussão sobre a hegemonia no plano internacional, que aponta repetidas mudanças dos centros hegemônicos, uma antiga e importante referência, a "sociedade nacional", cede lugar na análise ao conceito de "centros hegemônicos". 
A forma peculiar de internacionalização que se impõe sob o capitalismo monopolista também é responsável por esse deslocamento no plano das noções que balizam a análise. Florestan se dá conta de que "o capitalismo monopolista está alterando rapidamente o quadro dos ajustamentos entre nações desenvolvidas e subdesenvolvidas, estimulando o aparecimento de um 'padrão de interdependência' que subjuga de forma sem precedentes (sem nenhum vínculo 'colonial' ou 'imperialista') as economias satélites. ... Já não se pode pensar que 'internalização de centros de decisão' seja equivalente a 'nacionalização dos interesses econômicos' e produza autonomia de crescimento econômico, onde estejam presentes firmas que internalizam o fluxo do capitalismo monopolista" (Fernandes, 1967b:60). Com esse tipo de mudança na organização internacional do capitalismo, a antiga noção de autonomia, que o próprio Florestan contrapunha à heteronomia em bases nacionais, precisará sofrer modificações. Uma das suas características principais, que era a existência de centros de decisão "internos", é afetada pela produção internacionalizada por meio de empresas multinacionais. Aliás, a definição mesma da relação interno/externo precisará ser repensada.

Florestan conseguiu se manter fora do esquema básico de pensamento da ideologia desenvolvimentista. Há os que até se opõem àquela ideologia, mas permanecem prisioneiros do problema que ela impõe como se fosse realidade e que, na verdade, é produto ideológico, idéia produzida pela ideologia, no seu interior. Florestan percebeu essa malha e não se deixou envolver por ela. Criticou-a, de fora dela. E encontrou seus próprios caminhos, os construiu, para pensar a realidade brasileira naquele momento.

As características básicas já estavam colocadas por ele há algum tempo. No entanto, elas ganham especificações e desdobramentos. Sobressai a articulação entre a dependência e a organização social interna, especialmente no que concerne às classes sociais, suas relações entre si e com as formas de poder na sociedade dependente. A questão da dependência ao exterior tem também dimensões importantíssimas que são internas ao país dependente.

Florestan teoriza a situação brasileira e a heteronomia sobre questões que, em parte, estavam colocadas no debate intelectual a nível nacional e internacional, mas que ele retoma num outro patamar explicativo. A questão da dependência, por exemplo, tinha lastro nesse debate. Era uma idéia que tinha forte conotação política, mas que em geral era tratada na matriz do velho colonialismo. Florestan teve o mérito de, a quente, no calor do debate e muito cedo, ter o distanciamento e ao mesmo tempo o envolvimento necessários para teorizá-la como uma relação nova, com um objeto novo, que mudava a própria dimensão do problema e assim fornecia elementos inovadores e da maior relevância ao debate intelectual e político. 
E mais, na sua teorização também não se deixou cair no esquema fácil $\mathrm{e}$ funcional de pensar a dependência de nação a nação. Sua formulação acerca da heteronomia não tem como referência o Estado-nação. E a razão para isso é ter colocado as classes sociais no centro mesmo da sua análise. A ordem social constituída pelo capitalismo a nível mundial, por meio do exercício de hegemonias dos seus centros dinâmicos, organiza no próprio plano internacional a ordem social local das economias assim tornadas dependentes. Florestan entende que estas relações operam através dos sistemas de classes sociais, tanto nos "centros hegemônicos", quanto nos "satélites dependentes". As classes se constituem como classes no interior daquelas relações e por meio delas. Todas operam, direta ou indiretamente, como esteios mais ou menos importantes desse processo mesmo, mas só algumas se beneficiam dele e, no capitalismo dependente, de uma forma exacerbada quanto às relações sociais internas que engendram. Nas relações que as demais classes possam manter entre si e com as que ocupam as posições dominantes reside a possibilidade de transformação desta ordem social, o que Florestan coloca como condição mesma do desenvolvimento autônomo, contra a condição de capitalismo dependente.

Esse tipo de compreensão, que revela o entrelaçamento da ordem econômica capitalista com a ordem social local das sociedades dependentes por meio das classes sociais permite a Florestan, por exemplo, explicar formações ideológicas que fazem parte também daquele entrelaçamento. Diz: "as burguesias de hoje por vezes imitam os grandes proprietários rurais do século XIX. Apegam-se ao subterfúgio do desenvolvimentismo como aqueles apelaram para o liberalismo: para disfarçar uma posição heteronômica e secundária. $O$ desenvolvimentismo encobre, assim, sua submissão a influências externas, que se supõem incontornáveis e imbatíveis. A mesma coisa acontece com o nacionalismo exacerbado. Quando ele reponta, no seio dessas burguesias, quase sempre oculta algo pior que o fracasso histórico e a frustração econômica: envolve uma busca de esteios para deter a torrente histórica e preservar o próprio capitalismo dependente, e segundo valores provincianos" (Fernandes, 1967b:101).

Florestan trata as ideologias enquanto formas de subterfúgio, disfarce ou ocultamento. Elas encobrem a realidade, mas disfarçam sobretudo suas razões de ser e os objetivos que perseguem. Florestan revela aqui o desenvolvimentismo e o nacionalismo exacerbado como ideologias voltadas para a preservação do capitalismo dependente. $\mathrm{O}$ desenvolvimentismo se faz submissão, por dentro, à dependência. O nacionalismo exacerbado cumpriria a mesma função, ocultando no fundo sua tentativa de conter as possibilidades de transformação mais radical e mais profunda da realidade social dependente. 


\section{A revolução social como condição do desenvolvimento autônomo}

Em toda a sua produção sociológica, Florestan Fernandes sempre considera as forças sociais e suas relações referidas ao econômico, ao político ou ao cultural. Variam os enfoques adotados e, conseqüentemente, a relevância analítica atribuída às forças sociais. Variam também as dimensões que são privilegiadas, dependendo do objetivo do estudo.

Quando, porém, Florestan Fernandes teoriza o subdesenvolvimento em termos de capitalismo dependente, traz as classes sociais para o centro da sua formulação teórica, conferindo a elas um papel decisivo, o que vem alterar substancialmente os termos da questão. Nesse movimento, constitui uma abordagem e uma teorização efetivamente novas "da questão do desenvolvimento", o que o singulariza entre os teóricos que se situam no campo crítico do "subdesenvolvimento".

Já em 1960, aponta firmemente para a necessidade da inclusão das classes sociais no esquema analítico. Para ele, "as questões relacionadas com o desenvolvimento caem na esfera de consciência social dos homens. Elas fazem parte da porção do ambiente social que se está incorporando ou tende a incorporar-se ao sistema organizatório da sociedade, havendo por isso um mínimo de conformidade na percepção, na interpretação e na avaliação delas pelos agentes humanos". Alerta, porém, para a "existência de imensa gama de flutuações na maneira pela qual as classes sociais em presença tomam consciência, apreciam axiologicamente e procuram tirar proveito, mediante comportamento grupal organizado, das mudanças sociais em curso. Tais condições dependem, naturalmente, dos interesses, valores e estilos de vida social de cada classe, o que introduz elementos inevitáveis de divergência e até de conflito no comportamento coletivo dos homens, quaisquer que sejam os objetivos comuns, compartilhados de forma mais ou menos consciente" (Fernandes, 1960a:141; 1960b: 237).

Nenhum desenvolvimento se faz naturalmente, ainda que seja resultado de processos objetivos de determinação. O desenvolvimento é sempre obra dos homens. Quanto mais dificuldades e resistências se opuserem a ele, mais ele depende da consciência social dos homens. É bem esse o caso no Brasil, na América Latina, em todas as regiões heteronômicas do capitalismo em expansão. Para Florestan, a consciência social precisa ser pensada com relação às classes sociais enquanto sistema: "As classes sociais definindo-se umas quanto às outras, com seus interesses, sua capacidade de percepção, de organização e de ação específica. Seus interesses tendem a definir suas aspirações e seus movimentos de aproximação ou de afastamento das demais classes, grupos e camadas sociais. Mas este nunca é um processo direto e imediato, muito menos mecânico. Ele é 
sempre mediado pela consciência que se tenha dos próprios interesses e das possibilidades da sua satisfação.

Por outro lado, nesta altura Florestan pensa as "questões do desenvolvimento" através da categoria de heteronomia. Para ele, é claro que, se a ação deliberada dos homens na sociedade depende da consciência social, depende também, antes, das condições objetivas da realidade onde essa consciência se forma e para onde aquela ação se volta. As condições objetivas da realidade cultural subdesenvolvida apresentam caracteristicamente insuficiência de recursos racionais de pensamento e de ação (Fernandes, 1955a:185). A dependência cultural, como vimos, bloqueia a possibilidade de construção de um processo cultural dotado de dinamismo próprio. Não é, portanto, somente a ação voltada para a autonomização que é obstaculizada, mas a própria criação intelectưal espontânea ou, sob outra perspectiva, a consciência da própria situação.

Não é toda a sociedade que se encontra mobilizada pelo desenvolvimento e para ele. É apenas "uma porção do ambiente social", porção que, sabemos, é significativa na ocasião e é socialmente diferenciada, no sentido de abrigar diferentes setores produtivos e, conseqüentemente, envolver classes, camadas e grupos sociais distintos. Apesar dessa diferenciação interna, porém, em tảl "porção do ambiente social" existiria "um mínimo de conformidade na percepção, na interpretação e na avaliação delas [as questões do desenvolvimento] pelos agentes humanos". Ou seja, Florestan admite que há um processo de transformação social da realidade objetiva que está em curso e que há uma parcela da sociedade que percebe, interpreta e avalia essa transformação de forma minimamente comum. Isto quer dizer que, a par da transformação objetiva, também está ocorrendo um processo de formação de consciência social.

Neste processo, os cientistas. sociais encontram oportunidade e mesmo um certo nível de dever de oferecer à sociedade os conhecimentos que tenham conseguido elaborar sobre ela e que possam ajudar a entender acontecimentos e razões, que de outro modo não estão à disposição das pessoas em geral. De acordo com Florestan, "parece que cabe aos cientistas sociais latino-americanos extrema responsabilidade perante as transformações por que passam os seus próprios povos. Eles não podem isentar-se de sua condição participante de cidadãos - e de cidadãos que podem enxergar mais longe no mundo nebuloso em que vivemos. ... Os cientistas sociais não podem recuar, por temor à incompreensão e às conseqüências dela decorrentes, diante do dever de contribuir para o esclarecimento dos espíritos e a orientação positiva dos movimentos sociais. Mesmo que sua influência seja neutralizada, terão feito o que lhes competia na esfera de suas responsabilidades intelectuais e morais, colocando os conhecimentos da ciência ao alcance dos homens de ação e da opinião pública" (Fernandes, 1960b:243 e 244). 
Já tínhamos visto que, para Florestan, à responsabilidade científica sempre se agrega ou deve agregar-se a responsabilidade social do cientista. No caso de países dependentes, ele julga que essas responsabilidades se tornam ainda maiores. Nestas suas reflexões, podemos perceber em funcionamento sua crença na razão e na ciência e seu discernimento quanto às dificuldades à sua recepção, seja pelo poder, seja pela opinião geral.

Se o esclarecimento tende tantas vezes a criar incompreensões e reações adversas, dificuldades maiores se fazem sentir como reação de uma realidade fortemente estruturada que esteja passando por processos importantes de transformação. Tais resistências e entraves pertencem ao plano da realidade objetiva, antes de mais nada. Florestan defende a idéia de que, mesmo sob condições objetivas francamente adversas, é possível tomar consciência delas e dominá-las. Se tal formação de consciência e tal domínio da realidade não se produzem espontaneamente, cabe ao pensamento racional "ajudar os homens" a conseguilo. Florestan diz: "mesmo onde a desirabilidade dos fins chega a criar um estado de concordância fundamental entre as classes sociais, pode acontecer que os meios sociais disponíveis (seja em termos técnicos e econômicos, seja em termos de probabilidades de atuação organizada) suscitem limitações e impedimentos intransponíveis ou dificilmente superáveis. ... Na realidade, seria possível elevar também essa porção do ambiente social à esfera de consciência e de controle dos agentes humanos. ... O afã coletivo pelo 'desenvolvimento' não contribuirá, por si mesmo, para alterar o padrão e o ritmo da mudança social nos países latinoamericanos. Para se obter um efeito tão radical, é preciso auxiliar os homens a identificarem e a combaterem as condições e os fatores sociais mais profundos, que regulam em níveis muito baixos sua capacidade de atuação coletiva inovadora e impedem o recurso a técnicas sociais conhecidas de manipulação das forças que operam na porção organizada do ambiente" (Fernandes, 1960a:141-142; 1960b:237-238).

O argumento e a explicação apresentados pertencem ao quadro da determinação concreta das condições da vida social pela situação heteronômica. Mas, nesse texto, Florestan dá um passo adiante no esclarecimento da amplitude dessa determinação. Aprendemos com ele que a heteronomia produz divisões, dualidades, concentração - na produção, no poder, na renda, na sociedade. E que essas consequiências, tornadas fatos, contribuem para manter e ampliar a própria heteronomia. Para além das divergências e dos conflitos entre as classes sociais, quando entre elas se estabelece uma "concordância fundamental", em função de fins comuns, mesmo tal concordância vem a esbarrar em "limitações e impedimentos intransponíveis ou dificilmente superáveis". A vontade dos homens, enquanto vontade coletiva, fruto de acordo entre finalidades, se depara com uma realidade hostil à realização das transformações que essa vontade pretende. 
A suposição de uma comunidade de interesses confrontada com dificuldades sérias à implementação de ações voltadas à satisfação destes interesses comuns, traz conseqüências. Em primeiro lugar, suscita o reconhecimento da gravidade dessas "resistências" do "meio social", indicando a necessidade e a urgência de explicar suas origens mais profundas. Em segundo lugar, recomenda que tais explicações sejam postas logo à disposição "dos homens" para, na prática, ajudá-los a compreender de onde provêm os obstáculos concretos a que eles possam atingir seus objetivos, elevando assim o nível da consciência social. Em terceiro lugar, o rigor da pesquisa sobre as dificuldades e os entraves ao "afã coletivo pelo desenvolvimento" mostra a conveniência de dirigir o próprio foco da investigação sobre aquela suposta "comunidade de interesses", isto é, não simplesmente admiti-la a partir da sua suposta existência - ela que estava colocada pela proposta desenvolvimentista -, mas procurar tratá-la como hipótese e submetê-la a análise cuidadosa e criteriosa, tomando como objeto específico de estudo a composição das forças sociais empenhadas de fato na promoção e na aceleração do "desenvolvimento". Florestam dedica sua atenção e seu esforço nas três direções apontadas: aprofunda sua análise da heteronomia/dependência como explicação do subdesenvolvimento, atua no sentido de contribuir para a elevação da consciência social e não só desenvolve substancialmente suas pesquisas sobre as classes sociais no Brasil, como abre uma linha de investigação específica sobre a questão da "revolução burguesa" no Brasil.

Assume importância ímpar para a sua análise a forma como absorve as classes sociais no esquema teórico com que analisa o capitalismo dependente. Para ele, "a explicação sociológica do subdesenvolvimento econômico teria de ser procurada no mesmo fator que explica, sociologicamente, o desenvolvimento econômico sob o regime de produção capitalista: como as classes se organizam e cooperam ou lutam entre si para preservar, fortalecer e aperfeiçoar ou extinguir aquele regime social de produção econômica" (Fernandes, 1967b:2728). E entre as "proposições fundamentais para a compreensão do capitalismo dependente como fenômeno sociológico", Florestan coloca que "até hoje, os investigadores dos centros mais avançados lidaram com os problemas de interpretação das sociedades capitalistas dependentes como se o subdesenvolvimento fosse uma contingência ou uma condição transitória. Os investigadores oriundos dessas sociedades perfilharam tal ponto de vista ou negligenciaram a necessidade, puramente teórica, de associar o regime de classes e o capitalismo dependente à explicação sociológica do subdesenvolvimento" (Fernandes, 1967c:12-13). O sistema de classes, articulado nacional e internacionalmente pela condição de heteronomia, passa a ser encarado como fundamental para entender o funcionamento interno daquela condição, mas também o questionamento deste funcionamento e da condição mesma que o determina. 
Florestan leva muito a sério o condicionamento da produção de idéias pela inserção social de quem as formula. Para localizar e definir um problema, é preciso ter o que ele chama de "sensibilidade" para o problema, que é maior - pelo menos, tende a ser maior - para quem sofre o problema, e não para quem ganha com ele. Assim, acredita que os pesquisadores oriundos dos países dependentes tendem a ter mais sensibilidade para as questões envolvidas pela dependência do que os pesquisadores oriundos dos países "mais avançados". Deste modo, não considera as "explicações" diferenciadas do problema "subdesenvolvimento ou dependência" em termos meramente teóricos, mas tenta estabelecer nexos sociológicos entre tipos de produtores e tipos de produto. Curiosamente, na identificação dos tipos de produtores que encaminha no texto citado, ele aplica a própria teoria do capitalismo dependente, mas aponta para qualificar a diferença entre produtores se eles são ou não "oriundos dos centros mais avançados". Quer dizer, ainda não qualifica a sua diferença em função do regime de classes, $o$ qual acaba de afirmar como fundamental para aquela teoria.

Quando Florestan explica o subdesenvolvimento como sendo "gerado, condicionado e regulado a partir de fora", a conseqüência direta desta explicação é que, para anular o efeito, se ataque a sua causa, ou seja, que "a ruptura do subdesenvolvimento se identifica com o repúdio ao capitalismo dependente", o qual "só pode desencadear-se a partir de dentro". A condição para sair do estado de subdesenvolvimento é opor-se à condição de dependência. Não é, pois, o "desenvolvimento" que será capaz de vencer o "subdesenvolvimento". Sob a dependência, é "de dentro" que pode surgir o processo de negação da ordem capitalista dependente.

A proposta desenvolvimentista se articulava em torno da "aceleração do desenvolvimento", para o que era considerada como necessária a união de todos, bem como a identificação das "resistência sociais à mudança" e a luta contra elas. A ideologia desenvolvimentista identificava nessas resistências uma ameaça à ordem estabelecida, minando-a por dentro e, assim, acabava por se qualificar pela fórmula "mudar, dentro da ordem, para garantir a ordem".

Florestan negou a proposta desenvolvimentista da necessidade da "união nacional" para a aceleração do desenvolvimento - desenvolvimento esse que, afinal, era internacionalizado e reprodutor das relações de dependência causadoras do próprio subdesenvolvimento contra o qual se apelava à "união nacional". Em lugar da necessidade da aceleração do desenvolvimento, Florestan colocou a necessidade do fortalecimento da revolução social, como condição mesma daquela aceleração.

É importante assinalar que, em Florestan, essa discussão já estava presente em texto de 1960 , texto produzido, portanto, ainda sob a vigência do desenvolvimentismo de tipo juscelinista no Brasil. Afirma, por exemplo, naquela 
ocasião, que "a condição inicial para qualquer 'aceleração' do desenvolvimento social nos países latino-americanos consiste em fomentar as tendências à desintegração das diversas modalidades de 'antigos regimes' neles existentes" (Fernandes, 1960a:144; 1960b:248) Ou seja, para "conseguir ['acelerar' o desenvolvimento daqueles países], porém, torna-se mister amparar e fortalecer o processo de revolução social por que vêm passando os povos da América Latina desde sua independência política das metrópoles colonizadoras" (Fernandes, 1960a:145; 1960b:249). Florestan identifica como estando em curso na América Latina um processo já longo de transformação profunda da realidade social (revolução social). No entanto, nas condições dadas, tal processo depende de consciência e de mobilização para a luta por sua efetivação, luta que Florestan entende ser, antes de mais nada, contra a ordem estabelecida.

Portanto, quando ele fala no caráter coletivo desta consciência, desta mobilização e desta luta, está identificando forças sociais diferenciadas em torno da manutenção e da transformação dessa ordem, em termos não de consenso, ou união nacional, mas de classes, que se aproximam e cooperam, mas também que se opõem e lutam entre si.

Afirma que "em nenhuma alternativa é possível conceber qualquer modalidade de mudança social prescindindo-se da existência ou da formação de disposições coletivas para a mudança. O chamado 'umbral' do desenvolvimento só poderá ser alcançado, do ponto de vista sociológico, nas condições em que se encontram os povos latino-americanos, quando essas disposições tomarem por objeto a ordem social vigente" (Fernandes, 1960a:157; 1960b:263).

A discussão assim se desloca do campo do econômico para o campo do político, tendo no seu centro a questão: a quem interessa a mudança? Segundo Florestan, o "problema capital" é: "mudança social de caráter estrutural e controle do poder por círculos sociais conservadores são entidades que se excluem. O simples fato de uma sociedade comportar indefinidamente essa combinação já é, em si mesmo, um índice relevante de que a mudança estrutural conta com limitada viabilidade. Doutro lado, se tal combinação coincide com o uso indiscriminado do poder por aqueles círculos, então eles adquirem uma posição excepcional para agirem na defesa de interesses particularistas e, se necessário, para lutar contra a mudança. O elemento político se equaciona, para tais círculos, em termos simples: o uso do poder para conseguir o máximo de estabilidade social. Se isto for impossível, o uso do poder segundo alternativas que redundem no controle dos fatores da mudança social, na monopolização dos seus proventos de significação política e na contenção de suas tendências à aceleração. A lógica desse comportamento é bem conhecida. $O$ pensamento conservador não poderia proceder de outro modo, sem destruir-se. Para que as coisas tomem o rumo inverso, impõe-se que outros círculos sociais possam escolher entre diluir o presente 
no passado ou criar a sua própria história" (Fernandes, 1965:125-126). Esse é um texto de resistência e de luta. Florestan o escreve sob os impactos do golpe de 1964, segundo ele mesmo "sob grande tensão intelectual e moral", quando foi levado a "procurar explicações mais profundas da nossa situação históricosocial. Explicações em si mesmas objetivas, independentes e desafiadoras, que levantassem o véu do conformismo intelectual e da cumplicidade diante de classes dominantes estéreis e de militares de horizonte patriótico estreito" (Fernandes, $1967 \mathrm{c}: 7-8)$.

No texto de 1965 , é ressaltado o caráter contra-revolucionário do golpe de 1964, em que os "círculos sociais conservadores", pelo "uso indiscriminado do poder", lutam contra a mudança. A análise de Florestan explicita com clareza seu inconformismo e sua concepção sobre as condições de resistência e de reversão da situação. Menciona a possibilidade de que "as coisas tomem rumo inverso", desde que "outros círculos sociais" façam a opção de "criar a própria história". Todo o potencial político da luta contra a ditadura no sentido de uma luta de transformação da própria ordem social está colocado aí enquanto possibilidade concreta, sob uma concepção da ordem social e do poder que as vincula direta e profundamente às classes sociais.

Um pouco mais tarde, no início de 1967, e sempre a partir da perspectiva do desenvolvimento autônomo, Florestan vai dar ênfase à necessidade da construção política de uma vontade nacional. Preocupa-o “a integração do Brasil como uma sociedade nacional e sua posição no conjunto das demais sociedades nacionais que compartilham da mesma civilização". Sua orientação é bem clara: "o que deve nos interessar é o modo de participar do padrão dessa civilização" (Fernandes, 1967a:177). E indica o que a seu ver é o ponto fundamental da 'discussão. Diz que, “como se trata de uma relação - a relação do Brasil com as sociedades nacionais do mesmo círculo de civilização e, em particular com aquelas sociedades nacionais que detêm o controle do próprio processo civilizatório no âmbito dessa civilização - não se poderia alterar a atual situação unilateralmente. Para modificarmos essa posição relativa do Brasil e, com ela, o seu 'destino histórico', seria preciso introduzir alterações concomitantes em dois níveis distintos: o interno e o externo. Todavia, a organização e a orientação das forças que operam ao nível externo escapam ao controle de uma sociedade nacional determinada, especialmente se ela preenche a condição de uma sociedade satélite e dependente, especializada no consumo das invenções culturais e no atendimento das necessidades econômicas ou de outra natureza das sociedades nacionais a que se subordina. Por isso, o processo só pode ser (e, de outro lado, tem de ser) desencadeado a partir de dentro: através da modificação das estruturas sociais, econômicas e políticas da sociedade brasileira. Desse ângulo, o desenvolvimento não é um 'problema econômico' e tampouco um 'problema social', um 'problema cultural', um 'problema político' etc. Ele possui o caráter de um 
problema macrossociológico, que afeta toda a organização da economia, da sociedade e da cultura e que diz respeito, essencialmente, a todo o 'destino nacional', a curto ou a longo prazo" (Fernandes, 1967a:177-178).

As razões para que se produza o "querer coletivo" que conduza a luta contra a ordem social estabelecida se fará por força de necessidades e de conflitos sociais. Para Florestan, "apesar das instituições e dos valores sociais vigentes, a ordem legal criada pela República não abrange, eqüitativamente, todas as camadas sociais de todas as regiões do País. Tudo se passa como se os direitos e as garantias sociais, assegurados por essa ordem legal, fossem privilégios inconfundíveis das minorias que possuem condições econômicas, sociais e políticas para desfrutá-los e como se fosse indiferente, para a existência e para o futuro de uma sociedade nacional, que três quartos da sua população estivessem parcial ou totalmente banidos de suas estruturas de poder. Ora, nenhuma sociedade nacional pode existir, sobreviver e ao mesmo tempo construir um destino nacional, em tais bases. A destruição de estamentos e de grupos sociais privilegiados constitui o primeiro requisito estrutural e dinâmico da constituição de uma sociedade nacional. Onde essa condição histórica não chega ou não pode concretizar-se historicamente, também não surge uma nação e, muito menos, uma nação que possa apoiar-se num 'querer coletivo' para determinar, por seus próprios meios, sua posição e grau de autonomia entre as demais sociedades nacionais do mesmo círculo civilizatório" (Fernandes, 1967a:179-180).

Estas análises como que condensam a formulação teórica e a postura política de Florestan Fernandes no início de sua produção sociológica, até 1967. As linhas mestras já tinham sido indicadas desde 1960 , tanto no que diz respeito à percepção da condição de dependência, quanto no que se refere à concepção da necessidade da aceleração da "desagregação da ordem social existente" (Fernandes, 1960b:264), esta porque se necessitava de "mudança qualitativa e [de] sincronização dos processos de mudança progressiva, inconciliáveis com os padrões dominantes de organização da personalidade, da sociedade e da cultura" (Fernandes, 1960a:156; 1960b:261).

Nos textos de 1967, sua exposição especifica melhor as razões daquele caráter inconciliável. Sua análise identifica a condição de dependência, em nível externo e em nível interno. Externamente, ela tem como ponto fundamental ser uma relação definida pelo modo de participação das sociedades nacionais no padrão da civilização de que fazem parte, modo do qual resulta a situação de dependência. Internamente, a condição de dependência se exprime numa ordem social injusta e excludente, caracterizada pelo privilégio das minorias e pelo banimento das estruturas de poder de três quartos da população.

Por outro lado, Florestan expressa o objetivo que está valorando: a constituição da nação, dona do seu próprio destino histórico, capaz de alterar sua 
posição relativa diante das outras nações. $\mathrm{Na}$ argumentação de Florestan, tal objetivo supõe a reversão da condição de dependência, o que, por sua vez, não será possível sem a profunda transformação da ordem social vigente. $O$ primeiro requisito estrutural e dinâmico apontado para a constituição da sociedade nacional é "a destruição de estamentos e grupos sociais privilegiados".

Aqui, “a sociedade nacional” não é unidade de análise, não é referencial teórico, é objetivo político, é projeto, que, para concretizar-se, precisa da constituição e da ação de um "querer coletivo", este não como uma vontade consensual, mas como vontade nacional, que os três quartos de banidos das estruturas de poder possam opor ao privilégio das minorias.

\section{Notas}

1 Cf. Miriam Limoeiro Cardoso, Projeto de pesquisa Para uma história da sociologia no Brasil: a sociologia de Florestan Fernandes. São Paulo, IEA-USP, 1995.

2 Está colocada a questão de considerá-lo como fundador da sociologia científica no Brasil, hipótese importante que precisa ser devidamente demonstrada.

3 Cf. Miriam Limoeiro Cardoso, Ideologia do desenvolvimento - Brasil: JK-JQ ( $2^{\mathrm{a}}$ ed). Rio de Janeiro, Paz e Terra, 1978; id., La ideologia dominante: Brasil/América Latina. México, Siglo Xxı Editores, 1975 (esp. Introducción).

4 Para se ter uma idéia mais nítida de como esse período se situava na "carreira acadêmica" de Florestan Fernandes, talvez seja útil recorrer a uma de suas formulações a respeito. Diz ele: "A tendência intelectualista firmou uma tradição. Os 'anos de formação' correspondem aos 'anos de socialização acadêmica', ou seja, o período compreendido entre a escolarização ao nível do ensino superior propriamente dito e as últimas etapas da nobilitação para a 'carreira acadêmica'. No meu caso, se se entendesse a coisa nesse sentido, os anos de formação iriam de 1941 a 1953 (início do curso superior e a obtenção da livre-docência na cadeira de Sociologia I) ou, no máximo, até 1957, ano em que escrevi $A$ reconstrução da realidade nas ciências sociais (para mim um verdadeiro marco na definição da minha idade madura como sociólogo)" (Fernandes, 1977:142).

5 Cf. Miriam Limoeiro Cardoso, Compromisso ético e responsabilidade social do cientista (uma primeira aproximação), parte II de Para uma história da sociologia no Brasil: a obra sociológica de Florestan Fernandes - algumas questões preliminares, IEA-USP, Coleção Documentos, Série Teoria Política 8, 1994.

6 A produção e o debate intelectual deste período são muito importantes. O melhor entendimento de uma teorização como a de Florestan Fernandes requer, além do confronto com a produção dos seus pares na comunidade científica nacional e internacional, sua inserção nesse contexto cultural, a um tempo científico e político. Este, porém, não é o lugar, nem o momento, para propor tal contextualização. Não pretendo, agora, senão fornecer algumas indicações sumárias sobre a ideologia então domi- 
nante, que se constituía no grande fundo sobre o qual aquela produção e aquele debate se davam no Brasil.

7 Para maior detalhe a respeito desta ideologia, consultar Miriam Limoeiro Cardoso, Ideologia do desenvolvimento - Brasil: JK-JQ, cit., segunda parte.

8 A imagem da dependência, ou das dependências, como uma teia, e uma teia que é crescentemente tecida é, no mínimo, curiosa. No momento, apenas a indico, registrando que ela pode assumir interesse especial para essa análise no futuro.

\section{Bibliografia de Florestan Fernandes utilizada}

Tendo em vista que o estudo que fundamenta este artigo pretende acompanhar parte da trajetória de criação intelectual de Florestan Fernandes, é sobretudo importante identificar, em cada texto de sua autoria, com a máxima precisão possível, o momento de sua produção. Assim, são referidas as datas indicadas pelo próprio autor como sendo aquelas em que escreveu os textos ou as de sua primeira apresentação pública $\mathrm{cm}$ seminários, colóquios etc., além das datas de publicação. Nos casos em que o texto tenha sido publicado mais de uma vez, é feito também esse registro. Ao longo deste artigo, as referências bibliográficas de Florestan Fernandes apontam a data em que o texto foi escrito ou apresentado em público pela primeira vez. Salvo menção em contrário, o que aparece grifado nas citações está sublinhado no original.

(1946). Introdução a MARX, Karl. Contribuição à crítica da economia política (tradução de Florestan Fernandes). São Paulo, Flama, 1946 (republicado in FERNANDES, Florestan. Em busca do socialismo, últimos escritos e outros textos. São Paulo, Xamã, 1995).

(1955a). Ciência e sociedade na evolução social do Brasil. São Paulo, Revista Brasiliense, n. 6, jul./ago. 1956, (republicado como cap. III de FERNANDES, Florestan. $A$ etnologia e a sociologia no Brasil, ensaios sobre aspectos da formação e do desenvolvimento das ciências sociais na sociedade brasileira. São Paulo, Anhambi, 1958).

(1955b). Desenvolvimento histórico-social da sociologia no Brasil. Anhembi, v. VII, ns. 75/76, fev./mar. 1957 (republicado como cap. IV de FERNANDES, Florestan. $A$ etnologia e a sociologia no Brasil, cit.).

(1956) Tendências teóricas da moderna investigação etnológica no Brasil. Anhembi, ns. 72, 73 e 74, 1956-1957 (republicado como cap. I de FERNANDES, Florestan. $A$ etnologia e a sociologia no Brasil, cit.).

(1958). O padrão de trabalho científico dos sociólogos brasileiros. In: Coleção Estudos Sociais e Políticos, 3, Edições da Revista Brasileira de Estudos Políticos. Belo Horizonte, Universidade de Minas Gerais, 1958 (republicado como cap. IV de FERNANDES, Florestan. A etnologia e a sociologia no Brasil, cit.). 
(1959). Relações culturais entre o Brasil, o Ocidente e o Oriente. Comunicação apresentada ao Simpósio Intercámbio entre o Brasil e o Oriente, patrocinado por IBEC e Unesco, São Paulo, auditório da Universidade Mackenzie, 24 jun. 1959. Publicado como cap. IV de FERNANDES, Florestan. Mudanças sociais no Brasil. São Paulo, Difel, 1960.

(1960a). Esquema y ritmo del desarrollo en América Latina. Documento apresentado ao grupo de trabalho sobre Aspectos Sociales del Desarrollo Económico en América Latina, México, DF, 12 a 21 de dezembro de 1960, texto sob forma condensada. Publicado como cap. vII de DeVRIES, Egbert e José Medina ECHAVARRIA (eds.). Aspectos sociales del desarrollo económico en América Latina, v. I. Bélgica, Unesco, 1962 (republicado in CARDOSO, Fernando Henrique et al., América Latina: ensayos de interpretación sociológico-política. Santiago, Editorial Universitária, 1970).

(1960b). Padrão e ritmo de desenvolvimento na América Latina. Documento apresentado ao grupo de trabalho sobre Aspectos Sociales del Desarrollo Económico en América Latina, México, DF, 12 a 21 de dezembro de 1960, texto integral. Publicado como cap. 8 de FERNANDES, Florestan. A sociologia numa era de revolução social. São Paulo, Companhia Editora Nacional, 1962 ( $2^{\mathrm{a}}$ ed. reorganizada e ampliada, Rio de Janeiro, Zahar, 1976. As citações são extraídas da $2^{\text {a }}$ edição).

(1964). A revolução brasileira e os intelectuais - apêndice. Mensagem enviada aos formandos de 1964 da Escola de Sociologia e Política da Pontificia Universidade Católica do Rio de Janeiro, da qual o autor foi Patrono. A cerimônia realizou-se em 20 de dezembro de 1964. Publicado como parte do Cap. 5 de FERNANDES, Florestan, Sociedade de classes e subdesenvolvimento. Rio de Janeiro, Zahar, 1968.

(1965a). O problema da universidade. Artigo escrito no início de 1965 para a Revista Brasiliense. Ficou inédito em virtude do truncamento da circulação daquela revista. Publicado por Jornal da Senzala, São Paulo, n. 1, jan. 1968. (republicado como cap. I de FERNANDES, Florestan. Universidade brasileira: reforma ou revolução? São Paulo, Alfa Omega, 1975).

(1965b). A revolução brasileira e os intelectuais. Discurso de Paraninfo da Turma de 1964 da Faculdade de Filosofia, Ciências e Letras da Universidade de São Paulo, proferido em 23 mar. 1965. Publicado pela Revista Civilização Brasileira, n. 2, 1965 (republicado como cap. 5 de FERNANDES, Florestan. Sociedade de classes e subdesenvolvimento, cit.).

(1965c). A dinâmica da mudança sócio-cultural no Brasil. Lido parcialmente nos auditórios do Departamento de Relações Sociais da Harvard University e do Departamento de Sociologia Rural da University of Wisconsin, 1965. Publicado em Seara Nova, Lisboa, ns. de abr., jun. e ago. 1966; e em Cadernos Brasileiros. Rio de Janeiro, n. 35, maio/jun. 1966 (republicado como cap. 2 de FERNANDES, Florestan. Sociedade de classes e subdesenvolvimento, cit.).

(1966a). Crescimento econômico e instabilidade política no Brasil. Comunicação apresentada ao VI Colóquio Internacional de Estudos Luso-Brasileiros - Harvard University e Columbia University, set. 1966. Publicado em Revista Civilização Brasileira, ns. 11/12, dez.1966/mar.1967 (republicado como cap. 3 de FERNANDES, Florestan. Sociedade de classes e desenvolvimento, cit.). 
(1966b). FFCL-USP: aspectos estruturais de uma crise de crescimento. Publicado como cap. 4 de FERNANDES, Florestan. Educação e sociedade no Brasil. São Paulo, Dominus/Edusp, 1966.

(1967a). O desenvolvimento como problema nacional. Versão condensada da conferência realizada no Centro Acadêmico André da Rocha, 13 mar. 1967, sob o patrocínio de vários Centros Acadêmicos da Universidade Federal do Rio Grande do Sul e da Pontificia Universidade Católica do Rio Grande do Sul. Publicado como cap. 4 de FERNANDES, Florestan. Sociedade de classes e subdesenpolvimento, cit.

(1967b). Sociedade de classes e subdesenvolvimento. Trabalho apresentado ao segundo Colóquio Científico Ultramarino das Universidades e Escolas Superiores da Alemanha Ocidental, consagrado aos Problemas das Sociedades em Desenvolvimento Industrial. Universidade de Münster, 6 a 21 de novembro de 1967. Publicado como cap. I de FERNANDES, Florestan. Sociedade de classes e subdesenvolvimento, cit.

(1967c). Prefácio a FERNANDES, Florestan. Sociedade de classes e subdesenvolvimento, cit.

(1977) Em busca de uma sociologia crítica e militante, cap. 8 de FERNANDES, Florestan. A sociologia no Brasil, contribuição para o estudo de sua formą̧ão e desenvolvimento. Petrópolis, Vozes, 1977.

\title{
Resumo
}

Este é um estudo sobre o processo de criaf̧ão da nova maneira de pensar o Brasil e o subdesenvolvimento que Florestan Fernandes institui (sua problemática). Trata especialmente da construção do conceito de capitalismo dependente como uma forma assumida pelo capitalismo. Mostra como Florestan Fernandes, desde 1959-1960, rompendo com a ideologia dominante e a partir do par conceitual autonomia/heteronomia, caracteriza a situação heteronômica: externamente, enquanto dependência econômica, social, política, ideológica e moral; e internamente, através do sistema das classes sociais, classes que apóiam aquela dependência mas que, em determinadas condições, podem opor-se a elas. Mostra ainda como Florestan Fernandes considera que a revolução social contra a ordem capitalista dependente é condição para o desenvolvimento.

\begin{abstract}
This is a study on the creation process of the new mode of thinking Brazil and underdevelopment which is instituted by Florestan Fernandes (his problematics). The paper is specially concerned with the construction of the concept of dependent capitalism as a form of capitalism itself. It shows how Florestan Fernandes, since 1959-60, breaking away from the dominant ideology and departing from the conceptual pair autonomy/ heteronomy, characterizes the heteronomous situation: externally, as economic, social, political, ideological, and moral dependency; and internally, through the social class system,
\end{abstract}


classes which support such dependence but which, under certain conditions, may as well oppose it. It also shows how Florestan Fernandes believes that the social revolution against the dependent capitalistic order is a condition for development.

Miriam Limoeiro Cardoso, socióloga, é autora de La ideología dominante, Brasil/América Latina. México, Siglo XXI Ed., 1975; Ideologia do desenvolvimento, Brasil: JK-JQ. Rio de Janeiro, Paz e Terra, 1977 ( $2^{\mathrm{a}}$ ed.,1978); La construcción de conocimientos, cuestiones de teoría y método. México, Ed. Era, 1977. Atualmente desenvolve a pesquisa Para uma história da sociologia no Brasil: a sociologia de Florestan Fernandes. 